\title{
AN EXPLORATORY INVESTIGATION OF AN INTEGRATED CONTINGENCY MODEL OF STRATEGIC MANAGEMENT ACCOUNTING
}

\author{
Cadez Simon \\ Department of Accounting and Auditing \\ Faculty of Economics \\ University of Ljubljana \\ Kardeljeva ploscad 17 \\ 1000 Ljubljana \\ Slovenija \\ E-mail: simon.cadez@ef.uni-lj.si \\ Chris Guilding* \\ Service Industry Research Centre \\ Griffith University \\ Gold Coast Campus \\ PMB 50 Gold Coast Mail Centre \\ Queensland 9726
}

*Corresponding Author:

Chris Guilding

Fax: 61755528507

C.Guilding@griffith.edu.au

Acknowledgement: The authors would like to acknowledge the helpful comments provided by two anonymous referees. 


\title{
AN EXPLORATORY INVESTIGATION OF AN INTEGRATED CONTINGENCY MODEL OF STRATEGIC MANAGEMENT ACCOUNTING
}

\begin{abstract}
This study examines the effect of strategic choices, market orientation, and company size on two distinct dimensions of strategic management accounting (SMA) and, in turn, the mediating effect of SMA on company performance. A model is advanced and tested using structural equation modelling and data collected from a sample of 193 large Slovenian companies. The validity of the quantitative data findings has been appraised using qualitative data collected in ten exploratory interviews. The study's findings support contingency theory's tenet of no universally appropriate SMA system, with factors such as company size and strategy having a significant bearing on the successful application of SMA.
\end{abstract}

\section{Keywords}

Strategic management accounting, contingency theory, market orientation. 


\section{AN EXPLORATORY INVESTIGATION OF AN INTEGRATED CONTINGENCY MODEL OF STRATEGIC MANAGEMENT ACCOUNTING}

\section{INTRODUCTION}

A surge of interest in strategic management accounting (SMA) appears to have been provoked by widely published criticisms of conventional management accounting practice (Kaplan, 1984; 1986; Johnson and Kaplan, 1987; Ashton et al, 1991; Bhimani and Bromwich, 1992; Drury, 1992). These criticisms triggered a degree of soulsearching with respect to the potential for a more strategic role for management accounting together with normative commentaries concerning the application of an array of relatively novel approaches in the fields of costing, performance management, and strategic investment appraisal. This distinct accounting orientation and associated techniques are often collectivelly referred to as "strategic management accounting”.

The term "strategic management accounting" was first used by Simmonds (1981). Simmonds explored the provision of an accounting perspective on competitor appraisal, which represented a significant departure from accounting's conventional internallyfocussed orientation. While the SMA literature has since grown substantially (Simmonds, 1982; Bromwich, 1988; 1990; 1992; Shank and Govindarajan, 1988; 1992; 1993; Rickwood et al, 1990; Wilson, 1991; Ward, 1992; Palmer, 1992; Moores and Chenhall, 1993; Ryan, 1995; Roslender, 1995; Coad, 1996; Lord, 1996; Tomkins and Carr, 1996; Smith, 1997; Dixon, 1998; Roslender et al, 1998; Brouthers and Roozen, 1999; Szendi and Shum, 1999; Guilding et al, 2000; Cravens and Guilding, 2001; Hoque, 2001; Cadez, 2002; Tayles et al, 2002; Roslender and Hart, 2003; Bhimani and Langfield-Smith, 2007), there is still limited consesus on what is meant by "strategic management accounting”. Despite this attention, it is notable that SMA suffers from a relative dearth of empirically based research. The SMA empirical works conducted by Lord (1996), Szendi and Shum (1999), Guilding et al (2000), Cravens and Guilding (2001), Roslender and Hart (2003), and Bhimani and Langfield-Smith (2007) stand in relative isolation. The paradox of high SMA interest yet minimal empirical enquiry provided the broad motivation for the study reported herein.

The study has three main objectives. The first is to further refine the SMA notion. This refinement is provided by outlining two distinct, yet complementary, perspectives of SMA. The first perspective involves viewing SMA as comprising a set of strategicallyoriented (in contrast to accounting's conventional operational orientation) management accounting techniques. These techniques have already been commented on in several earlier works (Szendi and Shum, 1999; Guilding et al, 2000; Cravens and Guilding, 2001; Roslender and Hart, 2003). The second perspective considers the potential for greater management accounting engagement in the strategic management process. Traditionally, management accounting's jurisdiction has been viewed as confined to the role of providing information designed to assist managemement decision making and control (Kaplan and Atkinson, 1989). An evolving view holds that management accountants should assume a more active role in the strategic management process 
(Palmer, 1992; Bhimani and Keshtvarz, 1999; Scott and Tiessen, 1999; Nyamori et al, 2001).

The study's second objective is to further our appreciation of SMA systems in their organizational context by advancing a contingency-based SMA framework. Contingency theory posits that organizational structures and systems are a function of environmental and firm-specific factors (Anderson and Lanen, 1999; Haldma and Laats, 2002; Chenhall, 2003; Gerdin and Greve, 2004; Gerdin, 2005). In this study, four factors have been noted as potentially carrying significant implications for SMA system design. These are: (1) business strategy, (2) degree to which adopted strategy is deliberately formulated, (3) market orientation, and (4) firm size.

The study's third objective is to empirically investigate the validity of the proposed SMA contingency framework. While it is often claimed that contingency theory has become the dominant paradigm in management accounting research (Dent, 1990; Fisher, 1995), such a view is questionable. The central proposition of contingency theory asserts that organizational performance depends on the fit between organizational context and structure. This is a specific and complex proposition, because a conditional association of two or more independent variables with a dependant variable is hypothesized (Drazin and Van de Ven, 1985). A closer look into many "contingency studies" reveals, however, that conditional associations are rarely appraised. Most studies would be better described as "congruency" theory applications (a congruent proposition hypothesizes that a simple unconditional association exists among variables in the model). In this study, following Gerdin and Greve's (2004) hierachical taxonomy of forms of fit, a cartesian-contingency-mediation form of fit is tested via a structural equation model based on data collected from 193 large Slovenian companies.

Ittner and Larcker (2001) and Chenhall (2003) advocate that studying the role of novel management accounting practices within contemporary settings is necessary to ensure that management accounting research is relevant. Motivation for conducting this study in a Slovenian context derives from prior evidence suggesting that successful transition economies' economic and political upheavals are often associated with the application of relatively advanced business practices (Anderson and Lanen, 1999; Bogel and Huzsty, 1999; O’Connor et al, 2004). It should be acknowledged, however, that these are broadly based claims that are not specific to Slovenia.

Slovenia's change to a market economy began in 1991. At that time, commercial management expertise was very weak in areas such as marketing, general management and financial management (Edwards and Lawrence, 2000). Today, however, Slovenia represents an example of a successful transition from a socialist to a market economy (Edwards and Lawrence, 2000; Reardon et al, 2005) and appears to have well-developed accounting applications (Cadez and Guilding, 2007). Slovenia was granted full membership status to the European Union (EU) and NATO in 2004. In 2007 it was the first of 10 new EU economies to satisfy the criteria for adopting the Euro currency. ${ }^{1}$

\footnotetext{
${ }^{1}$ The 10 new countries admitted to the EU in 2004 were: Czech Republic, Cyprus, Estonia, Hungary, Latvia, Lithuania, Malta, Poland, Slovakia and Slovenia. Two further countries were admitted in 2007: Bulgaria and Romania.
} 
Slovenia can also be viewed as the most economically advanced of the 10 new EU countries, having recently surpassed the per capita GDP of Greece and Portugal. Recognition of Slovenian progress is also apparent from the fact that in 2008 it will be the first of the new EU states to take up presidency of the EU. The World Factbook (2006) records that in 2005, 60\% of Slovenia's GDP comprised services, 37\% came from manufacturing and 3\% came from agriculture. Manufactured goods, machinery and transport equipment, chemicals (including pharmaceuticals) and food comprise the main exports and total exports represent more than 50\% of Slovenia’s total GDP.

The remainder of the paper is organized as follows. In the next section, the SMA concept is further explored. Following this, the contingency model of SMA is developed, together with a set of testable hypotheses. In subsequent sections, the research method is described, the findings are outlined and the conclusion provides an overview of the most salient issues arising from the study.

\section{WHAT IS STRATEGIC MANAGEMENT ACCOUNTING?}

While the recent past has seen increased interest in SMA, the area is still underdefined and no universally accepted SMA framework exists (Tomkins and Carr, 1996; Coad, 1996; Nyamori et al, 2001; Roslender and Hart, 2003). A review of the literature suggests two perspectives on SMA can be taken. Firstly, SMA can be conceived of as comprising a set of strategically-oriented accounting techniques. Secondly, SMA can be viewed as concerned with the involvement of accountants in corporate strategic decision-making processes. These two perspectives are explored now.

\subsection{Strategic management accounting techniques}

Guilding et al (2000) provided an original distillation of SMA techniques and also criteria for viewing a particular accounting technique as "strategic". They noted that in much of conventional management accounting, a one year time frame is assumed and that an inward focus tends to predominate. These characteristics highlight a nonstrategic orientation in much conventional management accounting, as strategy implies a long-term future-oriented time frame and an externally-focussed perspective (Andrews, 1987; Mintzberg, 1987a; Mintzberg et al, 1995; Hunger and Wheelen, 1996; Porter, 1996). Guilding et al (2000) consequently advocated that these characteristics might be usefully drawn upon when determining what accounting techniques qualify as SMA. In their view, the techniques should demonstrate degrees of the following orientations: environmental (outward-looking) and/or long-term (forward-looking).

Employing these criteria, Guilding et al (2000) drew 12 SMA techniques from the literature. In a subsequent work, Cravens and Guilding (2001) added another three techniques. Drawing extensively on these works, 16 SMA techniques have been identified for analysis in this study. These techniques have been classified into five broad categories. Three of the categories correspond to underlying themes of management accounting acknowledged in many management accounting texts: (1) costing, (2) planning, control and performance measurement, and (3) decision-making. 
The remaining two categories have been labelled "competitor accounting" and “customer accounting”. The techniques are presented in Table 1.

\section{INSERT TABLE 1 ABOUT HERE}

\subsection{Accountant's participation in strategic decision making processes}

Paralleling the development of strategically oriented management accounting techniques, several recent commentaries suggest that accountants are assuming a greater role in the strategic management process (Fern and Tipgos, 1988; Palmer, 1992; Bhimani and Keshtvarz, 1999). Chenhall (in press) feels SMA practices have moved management accounting from an emphasis on operational issues to a more strategic orientation through an integration of customers, processes, HR and financials. Some see the significance of this to be such that a new concept, "the strategic accountant", has emerged.

As a reaction to more competitive and uncertain market environments, firms have adopted a more pronounced customer oriented posture. This has been manifested by the emergence of more cross-functional team-based structures (Scott and Tiessen, 1999; Baines and Langfield-Smith, 2003; Chenhall and Langfield-Smith, 2003; Rowe et al, in press). The term 'horizontal organization' has evolved to reflect organisations that emphasise the integration of activities across the value chain to support a customerfocused strategy, thereby flattening conventional vertical structures (Chenhall, in press).

Oliver (1991) and Scott and Tiessen (1999) argue that in stark contrast to their more traditional counterparts, strategic accountants are integral to strategic decision-making processes. The more mundane accounting tasks traditionally associated with the profession are being increasingly automated, freeing accountants to become involved in broader spheres of management activity. Strategic accountants can be viewed as proactive in analyzing broader business management issues rather than those narrowly defined by a financial orientation, and also more customer-oriented by providing greater counsel to clients (Coad, 1996; Chenhall and Langfield-Smith, 1998a; Nyamori et al, 2001). Roslender and Hart (2003) see SMA as intimately associated with marketing management.

This concept of strategic accounting builds on close relationships with non-accounting personel, where accountants assume a liaison role across functional boundaries and between levels of management (Coad, 1996; Parker and Kyj, 2006; Rowe et al, in press). In the literature, several terms have emerged in connection with this liaison role: business partnership (Oliver, 1991), coordination (Palmer, 1992), inter-departmental teams (Scott and Tiessen, 1999), teamwork (Bromwich, 2000), interfunctional cooperation (Roslender and Hart, 2003), team-based structures (Baines and LangfieldSmith, 2003), cross-functional teams (Rowe et al, in press), and horizontal accounting (Chenhall, in press). In the past, there appears to have been a tendency for parochial, functionally based, claims to data ownership which have impeded centralised 
information gathering. This appears to be becoming less prevalent in contemporary settings (Rowe et al, in press). Brouthers and Roozen (1999) propose that the process of information management be centralized in the accounting department, since accountants are already trained in data management.

These changes signify a dramatic shift in the underlying accounting paradigm. Strategic management accountants are no longer seen as just information providers, they are seen more as active players in the strategic management process, with power to achieve their own ends (Chenhall, 2003). Roslender et al (1998) note, however, that if accountants cannot cope with the challenges presented by this evolving role, then another function will move to provide information management services. Hoque (2001) feels accountants have historically exhibited an adeptness when reacting to new management contexts and sees no reason why the emergence of the strategic accountant should not be consolidated.

\section{TOWARDS A CONTINGENCY FRAMEWORK OF STRATEGIC MANAGEMENT ACCOUNTING}

Chenhall (2003) has provided an overview of contingency-based studies of management accounting. These studies have a long tradition dating back to the works of Gordon and Miller (1976), Waterhouse and Tiessen (1978), Ginzberg (1980), and Otley (1980) and the contingency approach quickly became the dominant paradigm in empirical management accounting research (Dent, 1990; Fisher, 1995).

Chenhall and Langfield-Smith (1998b) and Chenhall (2003) contend that contingencybased management accounting research should employ organizational performance as the dependant variable, a view suggesting that many studies that have been described as “contingency-based” studies (e.g., Gordon and Narayanan, 1984; Chenhall and Morris, 1986; Bruggeman and Van der Stede, 1993; Carr and Tomkins, 1996; Fisher, 1996; Libby and Waterhouse, 1996; Chow et al, 1999; Guilding, 1999; Reid and Smith, 2000; Moores and Yuen, 2001; Guilding and McManus, 2002, Haldma and Laats, 2002; Sharma, 2002; Gerdin, 2005; O’Connor et al, 2006), might be better described as applications of a "congruency paradigm”.

Another issue relating to contingency-based studies concerns the operationalisation of contingency fit. Drazin and Van de Ven (1985) see the emergence of three different approaches to appraising fit: selection, interaction and systems. The studies identified in the preceding paragraph fall within the selection approach, signifying they do not examine whether the context-structure relationship affects performance. The interaction approach has also been used relatively widely (e.g., Govindarajan and Gupta, 1985; Abernethy and Guthrie, 1994; Gul and Chia, 1994; Mia and Chenhall, 1994; Chenhall, 1997; Ittner and Larcker, 1997; Abernethy and Brownell, 1999; Davila, 2000), despite the ambiguities that render this approach methodologically problematical (see Hartmann and Moers, 1999; 2003; Gerdin and Greve, 2004). A systems approach, addressing multiple contingencies simultaneously, has been much less extensively applied (e.g., Selto et al, 1995; Chenhall and Langfield-Smith, 1998b). Chenhall (2003) provides an 
extension to Drazin and Van de Ven's (1985) classification by referring to a fourth structural relationship category that concerns intervening variables.

While these issues have no doubt contributed to the fair degree of inconsistent findings emanating from this body of management accounting work, certain themes and consistencies that provide a basis for further model development can be identified (see Fisher, 1995; Langfield-Smith, 1997; Ittner and Larcker, 2001; Chenhall, 2003; and Gerdin and Greve, 2004). We have little in the way of prior empirical observations upon which to build a contingency theory of SMA, however. This problem is exacerbated by the inconsistent interpretations of what constitutes SMA. For the purpose of this study, it was therefore important that SMA be identified with sufficient clarity to enable it to be viewed as comprising a coherent subset of management accounting practices. As already noted, Guilding et al's (2000) view of SMA as comprising techniques that are environmental (outward-looking) and/or long-term (forward-looking) has been drawn on in this study. This operationalisation carries a subtle, yet significant, unifying aspect. As noted by Guilding et al, the orientation of most conventional management accounting practices appears to be relatively distinct from SMA's orientations, due to their tendency to exhibit an inward looking, short-term and historically focused nature. This signifies that the SMA practices examined in this study focus on an information set that is fairly distinct from the information set captured by conventional management accounting practices.

Drawing on Fisher's (1995) view that the ultimate goal of contingent accounting research should be to develop and test a comprehensive model that includes multiple elements of accounting systems and multiple contingent variables, Figure 1 presents a model concerned with the contingency context of SMA. The model includes four contingency factors, the two perspectives of SMA noted above and organizational performance as a dependent variable.

\section{INSERT FIGURE 1 ABOUT HERE}

At the heart of the model are SMA usage (this refers to the usage of SMA techniques) and accountants' participation in strategic decision making processes. Consistent with prior related contingency-based studies (e.g., Chenhall and Langfield-Smith, 1998b; Anderson and Lanen, 1999; Guilding, 1999; Hoque and James, 2000; Cravens and Guilding, 2001; Guilding and McManus, 2002; Gerdin, 2005; O’Connor, 2006), both these general level (holistic) dimensions of SMA are modeled as endogeneous constructs in the model.

The contingency factors identified as potentially implicated in the design of effective SMA (exogenous constructs in the model) derive from conventional theories of organizational structure, referred to as the strategy-structure-performance paradigm by Anderson and Lanen (1999). Hambrick (1980) sees strategy as a concept particularly worthy of empirical investigation due to its potential association with many other organizational facets. In this study the focus is on business level strategy which has been 
operationalized using Miles and Snow's (1978) prospector/defender typology, due to its applicability across a range of industrial settings (Smith et al, 1989).

Most early descriptions of strategy imply that it arises from a deliberate stream of decisions (Miles and Snow, 1978; Andrews, 1987), however it appears many organizations' strategy can be characterised better as emergent rather than predetermined (Mintzberg, 1987a; 1987b; Mintzberg et al, 1995). Mintzberg (1987b) sees strategy as a craft and stresses the ambiguous and messy nature of strategic decisions. Most empirical management accounting research concerned with strategy presumes deliberate strategy formulation (Langfield-Smith, 1997). Where strategy formulation has less of a predetermined and deliberate orientation, formal management accounting systems imposing constraints and discipline may be counter-productive (Ittner and Larcker, 1997). The relatively under-explored nature of this dimension of strategy motivated its inclusion in the SMA examination reported herein. ${ }^{2}$

The inclusion of market orientation for examination in the study was also partially motivated by a lack of recognition given to the construct by accounting researchers. This is somewhat surprising, given the importance afforded to this variable by marketing academics. Narver and Slater (1990) view market orientation as central to modern management and strategy. It appears particularly appropriate for inclusion as a contingent factor in this study as it appears to bear a close association with the distinctive characteristics of SMA (Roslender and Hart, 2003). The inclusion of company size in the model was motivated by its reported contingent significance in several prior accounting studies (Merchant, 1981; Libby and Waterhouse, 1996; Guilding, 1999).

The dependant variable in the model is company performance. The fundamental tenet of contingency theory holds that company performance is a product of an appropriate fit between the structure (SMA system) and context (contingency factors). Consequently, it is assumed that both high and low performing companies exist as a result of more or less compatible combinations of context and structure (Ittner and Larcker, 2001; Gerdin and Greve, 2004). Stated alternatively, good fit implies enhanced performance, while poor fit implies diminished performance (Chenhall, 2003).

In this study, following Gerdin and Greve's (2004) taxonomy of forms of contingency fit, a cartesian-contingency-mediation form is tested. At the top level, the cartesian and configuration forms represent conflicting paradigms. Advocates of a cartesian approach argue that fit between context and structure falls within a continuum. This is contrary to analysts advocating a configuration approach which sees only a few states of fit. In the contingency approach, fit is understood as signifying a positive impact on performance due to certain combinations of context and structure. This can be distinguished from the

\footnotetext{
2 This aspect of strategy is especially pertinent in transition economies, such as Slovenia, because it is often argued that management in these countries only became immersed in serious strategic planning following the conversion to a market-based economy (Bogel and Hustzty, 1999). This might well signify high variability with respect to the degree that strategy formulation is conducted in a deliberate manner in transition economies.
} 
congruent approach which assumes that structure depends on context, without any examination made of whether this relationship affects performance.

\subsection{Hypotheses relating SMA to performance}

\section{SMA usage - performance}

The major function of an information system is to support managerial decision-making and control (Gelinas et al, 1998; Abernethy and Bouwens, 2005). Gupta (1987) argues that unless an organization's strategic information-processing capacity adequately meets its needs, the decisions that emerge will be flawed or late, thereby resulting in suboptimal performance. These expectations derive from economic models of decision making which assert that in uncertain conditions, the provision of better information results in improved resource allocation (Baines and Langfield-Smith, 2003; Christensen and Demski, 2003) and an enhanced positive outcome likelihood (Christensen and Feltham, 2003). A conditional association is thus assumed that better information facilitates more effective managerial decisions, which in turn enhance organizational performance (Baines and Langfield-Smith, 2003; Chenhall, 2003). While this relationship might be intuitively appealing, Chenhall (2003) warns against poorlyconceived leaps of logic. The exact nature of the relationship is ambiguous (Baines and Langfield-Smith, 2003) as the efficacy of MAS is dependent on organisational contextual factors (Chenhall, 2007) and its compatibility with managers' mental models (De Haas and Algera, 2002).

The relationship between management accounting usage and performance has been subjected to extensive empirical investigation. This accumulated work provides a somewhat equivocal picture (Chenhall and Moers, 2007). While most studies provide some support for the view that greater management accounting (broad scope information) usage is positively associated with performance (e.g. Abernethy and Guthrie, 1994; Gul and Chia, 1994; Mia and Chenhall, 1994; Chong and Chong, 1997; Mia and Clarke, 1999; Scott and Tiessen, 1999; Vandenbosch, 1999; Hoque and James, 2000; Cravens and Guilding, 2001; Baines and Langfield-Smith, 2003; Ittner et al, 2003; Mahama, 2006), in many of these studies the relationship is inconclusive and context dependent. For example, the use of broad scope information has been found to have a more positive effect on performance in prospector than in defender firms (Abernethy and Guthrie, 1994), in the presence of high environmental uncertainty (Gul and Chia, 1994; Agbejule, 2005), and for marketing managers relative to production managers (Mia and Chenhall, 1994). Further, team performance has been observed to be higher when a comprehensive measurement system is combined with greater participation in performance target setting (Scott and Tiessen, 1999). Ittner et al (2003) report that broad set information usage is positively associated with stock returns, however it is not associated with ROA and sales growth. Abernethy and Bouwens (2005) claim an important intervening role for user satisfaction in the relationship between acceptance of accounting innovations and performance. Some studies have documented no, or even a negative, association between accounting information and performance. Ittner and Larcker (1997) observed several strategic control practices to be negatively associated with performance. Perrera et al (1997) found no association between use of non-financial performance measures and performance. Agbejule (2005) 
reports that under low levels of perceived environmental uncertainty, sophisticated MAS has a negative effect on performance.

While acknowledging these studies' mixed outcomes, there appears to be a preponderance of findings pointing to a positive association between accounting information usage and performance. In the context of this study, it is also important to recognise SMA's quality of providing incremental information not garnered by a conventional accounting system. These factors have motivated the following hypothesis.

HЗa: Greater SMA usage is positively associated with performance.

Strategic decision making participation - performance

In increasingly competitive and uncertain market contexts, the creation of interdepartmental teams can improve the speed and quality of an organization's reaction to environmental developments, thus improving performance (Scott and Tiessen, 1999; Baines and Langfield-Smith, 2003; Rowe et al, in press). Heterogeneous senior management teams are better equipped to recognize strategic opportunities, and the representation of a greater breadth of functional perspectives enhances more informed strategy identification (Naranjo-Gil and Hartmann, 2007). Again, a conditional association is assumed that increased participation facilitates more effective managerial decisions, which in turn enhances organizational performance (Wooldrige and Floyd, 1990; De Haas and Kleingeld, 1999). Relative to their more traditional counterparts, strategic accountants can be seen to provide a distinct perspective when acting as an integral part of key organizational decision-making processes (Oliver, 1991, Scott and Tiessen, 1999). By being customer-oriented, proactive in analyzing business issues, liaising across functional boundaries and levels of management (Coad, 1996; Parker and Kyj, 2006; Rowe et al, in press), and by centralizing information management in modern intelligence centres, the relevance, accuracy and timeliness of information is increased (Brouthers and Roozen, 1999). Further, by nurturing a partner relationship with all the functions in the business they can add value to the decision-making process (Wooldridge and Floyd, 1990; Nyamori et al, 2001; Rowe et al, in press), thereby facilitating improved performance.

The relationship between participation and performance has been the subject of extensive management accounting empirical investigation, however the vast majority of studies have focused on budgetary participation and job performance (e.g. Mia, 1989; Nouri and Parker, 1998; Shields et al, 2000; Clinton and Hunton, 2001; Lau and Lim, 2002; Parker and Kyj, 2006; Chong and Johnson, 2007). Prior works investigating participation in strategic decision-making and organizational performance are few. Wooldridge and Floyd (1990) provide evidence that middle management involvement in strategy is associated with improved performance. Scott and Tiessen (1999) find that inter-departmental involvement has an indirect positive effect on team performance via the application of more diverse performance measures. Contrary to these findings, Chenhall and Langfield-Smith (2003) document a case study analysis where team-based initiatives did not appear to enhance performance. As the prior empirical literature concerning a relationship between inter-departmental participation and performance is 
relatively sparse, the following hypothesis has been primarily informed by what appears to be the conventional normative view.

H3b: Greater accountant participation in strategic decision making is positively associated with performance.

\section{Strategic decision making participation - SMA usage}

Greater involvement of accountants in strategy formulation and implementation will inculcate accountants with a more profound appreciation of the nature of the information needs posed by strategic management. In turn, this can be expected to result in accountants instigating accounting innovations (Abernethy and Bouwens, 2005), such as novel SMA techniques, that are more market and future focused (Coad, 1996; Otley, 1999; Nyamori et al, 2001). Further, accountants' involvement in strategic decision making will instill a greater appreciation of the justifiability of expending resources developing SMA systems and also incurring on-going costs associated with running and maintaining the systems (Christensen and Demski, 2003; Christensen and Feltham, 2003). A positive association between participation in strategic decision making and SMA usage therefore appears likely, as greater participation can be seen as providing both a motive and a pressure for accountants to add value to the strategic decisionmaking process (Oliver, 1991).

There is some empirical evidence supportive of such an expectation. Abernethy and Bouwens (2005) found that decision-rights' decentralisation is a factor that contributes to the effective implementation of accounting innovations. Baines and Langfield-Smith (2003) report that greater use of team-based structures results in greater reliance on nonfinancial management accounting information. This is also consitent with Gerdin's (2005) finding that organizations tailor the design of management accounting systems (MAS) to organisationally contingent control factors. On the other hand, Naranjo-Gil and Hartmann (2007) found no relationship between top management team heterogeneity and broad scope design of MAS in Spanish public hospitals. Further, Chenhall and Langfield-Smith (1998a) suggest a reciprocal relationship signifying accountants' participation in organizational change is dependent on senior management's support for accounting innovations. Again, in light of the limited prior empirical findings, the following hypothesis has been motivated primarily by a priori reasoning and what appears to be a consensus view in the normative literature.

H2e: Greater accountant participation in strategic decision making is positively associated with SMA usage.

\subsection{Hypotheses relating contingency factors, SMA system, and performance}

\section{a) Business strategy}

Miles and Snow (1978) identified three preferred organizational strategies (prospectors, analyzers, and defenders), and noted a fourth type (reactor) that they viewed as unsustainable. Miles and Snow see analyzers as adopting a hybrid form of strategy that manifests both defender and prospector attributes and considerable evidence suggests that defenders and prospectors define a continuous spectrum with analyzers represented 
around the mid-point of the continuum (Smith et al, 1989; Shortell and Zajac, 1990; Doty et al, 1993; Anderson and Lanen, 1999). Prospectors are seen as continually searching for product and market opportunities and as being the creators of innovation in a market. Defenders on the other hand are less dynamic, the key to their success is a focus on efficency. Since environmental and future orientation are prominent factors in both a prospector type strategy and SMA, we expect SMA techniques to be more widely applied in prospector than defender organizations. This is consistent with Guilding's (1999) reported positive relationship between the application of a prospector strategy and competitor focused accounting.

H2a: SMA usage is greater in prospector type companies than in defender type companies.

Adopted business strategy can be expected to influence the degree of accountants' participation in the strategic decision making process. Prospectors are continually searching for opportunities in the environment, while defenders focus on efficiency. In the language of Porter (1996), prospectors are more concerned with strategic positioning, while defenders are more concerned with operational effectiveness. Since strategy making requires broad inter-functional discussion (Palmer, 1992; Bromwich, 2000; Nyamori et al, 2001), while operational efficiencies tend to be sought with an intra-departmental philosophy, we expect accountants' participation in strategic decision making processes to be greater in organization's applying a prospector-type strategy.

H1a: Accountants' participation in strategic decision making is greater in prospector type companies than in defender type companies.

\section{b) Deliberate strategy formulation}

This strategic dimension focuses on the extent to which a company adopts a deliberate approach in its strategy formulation. Mintzberg (1987a) proposes that strategy is a pattern in a stream of actions, regardless of whether the pattern is intended. This suggests firms can differ with respect to whether they exhibit a deliberate and predetermined strategy formulation orientation or a more emergent strategy formulation orientation where patterns develop in the absence of intentions, or inspite of them. In practice, pure deliberate and pure emergent strategies are uncommon (Mintzberg, 1987b; Mintzberg et al, 1995). A deliberate strategy is a consciously intended course of action implying constant discussion about strategic actions, whereas an emergent strategy highlights the ambiguous nature of strategic decisions implying considerable flexibility (Langfield-Smith, 1997; Bhimani and Langfield-Smith, 2007). The more active management of strategy in those organizations practising a deliberate strategic management philosophy suggests a greater call for strategically oriented information such as that provided by an SMA system. This rationale motivated the following hypothesis:

H2b: SMA usage is greater in companies that take a deliberate approach to strategy formulation. 
A deliberate strategy, represented as a consciously intended course of action, implies frequent discussions about strategy where for its effectivenes the involvement of all functional areas, including (strategic) accountants, is required (Bromwich, 2000). It signifies greater intra-organizational debate and deliberation concerning what strategy is to be pursued. Hence, we posit that a more deliberate strategy formulation orientation results in greater accounting participation in strategic decision making processes.

H1b: Participation of accountants in strategic decision making is greater in companies that take a deliberate approach to strategy formulation.

Fisher (1995) claims that relationships between contingent factors are poorly documented. As a result, he promotes exploration of these relationships, although he warns that this can lead to a problem of conflicting contingencies. Following Fisher's encouragement, it appears reasonable to expect a relationship between the two dimensions of strategy under analysis. As companies applying a prospector strategy have to make strategic decisions with respect to what type of product/market innovations should be pursued and also the timing of product/market launches, it appears reasonable to expect prospectors to take a relatively deliberate approach to strategy formulation. In effect, prospecting decisions will have to be deliberated (Davila, 2000). This does not appear to be as much the case in defenders as the thrust of their strategy is at an operational, efficiency seeking level (Porter, 1996). Consistent with this reasoning, and supported by evidence from Simons (1987), it is expected that strategic management processes are more structured (deliberate) in prospector than in defender organizations.

H0: Deliberate strategy formulation is more developed in prospector than defender organizations.

\section{c) Market orientation}

A market orientation philosophy holds that planning and coordination of all company activities is focused on the primary goal of satisfying customer needs (Jaworski and Kohli, 1993; Walker et al, 1998). Market orientation can thus be defined as a business culture that effectively and efficiently creates superior value for customers (Narver and Slater, 1990). Narver and Slater see the concept as comprising three behavioral components and two decision criteria: customer orientation, competitor orientation, interfunctional coordination, a long-term focus, and a profit objective. As many of these facets are closely aligned to SMA, a positive relationship between market orientation and SMA usage is anticipated. Further, Guilding and McManus (2002) note a positive association between market orientation and the application of customer accounting.

H2c: SMA usage is greater in market-oriented companies.

Marketing academics and managers have continuously claimed that increased levels of market orientation are consistent with higher levels of market performance (Narver and Slater, 1990; Walker et al, 1998). As there is ample evidence supporting this proposition (Narver and Slater, 1990; Jaworski and Kohli, 1993; Slater and Narver, 1994), the following hypothesis has been developed. 
H3c: Market orientation is positively associated with performance.

d) Company size

It is an enduring finding that company size is positively related to accounting sophistication (Merchant, 1981; Libby and Waterhouse, 1996; Guilding, 1999). Company growth poses increased communication and control problems, therefore accounting and control processes become more specialized and sophisticated (Hoque and James, 2000). Further, increased company size results in lower relative costs (i.e. per sale) of information processing (Johnson and Kaplan, 1987; Guilding, 1999). Consistent with this rationale, the following hypothesis has been posited.

H2d: SMA usage is greater in larger companies.

\section{RESEARCH METHOD}

\subsection{Sampling procedure}

Data were collected using a mailed questionnaire survey. An initial sample was drawn from the Slovenian Chamber of Commerce and Trade disclosure of the 500 largest Slovenian companies (in terms of total revenue). This listing includes all industrial sectors except for financial intermediaries. To include financial intermediaries in the raw sample, two further databases were drawn upon: the Slovenian Banking Association database and the Slovenian Insurance Association database. This resulted in a raw sample of 520 companies. A second size filter was imposed to screen out companies with less than 100 employees. The sample was further reduced due to incorrect or incomplete mailing addresses for some cases. The final sample comprised 388 companies.

As part of a strategy to develop an accurate mailing list and secure a high response rate, a phone call was lodged with each company and the name of the most suitable person to complete the survey was identified. These were typically the Chief Accountant, Chief Controller, or Chief Financial Officer. In most cases, the particular manager was spoken to and the purpose of the research explained. The mailed survey package included a covering letter explaining the purpose of the research, a copy of the survey with a glossary of terms used and a postage-paid reply envelope. The first mailing resulted in 124 usable responses. A reminder letter was posted one month following the initial mail-out. This yielded an additional 69 responses. Thus the overall usable response rate was $49.7 \%$.

The industrial sectors represented in the sample analysed are presented in Table 2. Companies comprising the sample had an average annual sales level of €92.7 million. The smallest company's annual sales level was $€ 13.5$ million and the largest company's annual sales level was $€ 1.2$ billion. In terms of employees, the companies analysed had an average number of 747 employees, with the smallest company employing 104 and the largest company employing 8,765 staff. 
INSERT TABLE 2 ABOUT HERE

To investigate for possible non-response bias, Kolmogorov-Smirnoff tests of differences in the responses provided by early and late respondents (the first and last $25 \%$ of questionnaires returned) were conducted. No significant differences $(p<0.05)$ in the data provided by these sub-groups were noted for any questions posed. While this suggests little concern for non-response bias, it should be acknowledged that accountants in firms with relatively sophisticated accounting systems may have been more inclined to respond than those in firms with under-developed accounting systems.

In addition to the quantitative data collected, qualitative data has been collected by interviewing senior accountants in ten of the surveyed organizations in order to secure a deeper understanding of the nature of SMA and its context and also to review the validity of the quantitative data findings. The companies represented by the interviewees ranged in size and were drawn from a wide range of industrial sectors (see Table 3). All interviews were conducted at the subject companies' premises, were tape recorded, and had an average duration of around 45 minutes. All interviews were transcribed and translated into English by a bilingual native Slovenian.

\section{INSERT TABLE 3 ABOUT HERE}

\subsection{Variable measurement}

SMA usage

The degree of SMA technique usage was measured using the same approach as Cravens and Guilding (2001) and Guilding and McManus (2002). Following the question "To what extent does your organization use the following techniques?", the 16 SMA techniques were listed together with a Likert-type scale ranging from "1" (not at all), to "7” (to a great extent). A glossary containing definitions of the SMA techniques was provided to aid interpretation (see Appendix).

Accountant's participation in strategic decision making

The measure used draws on Wooldridge and Floyd's (1990) instrument designed to assess middle management involvement in strategic decision making. Respondents were asked to record their participation with respect to five aspects of strategic management: (1) identifying problems and proposing objectives, (2) generating options, (3) evaluating options, (4) developing details about options, and (5) taking the necessary actions to put changes into place. The scale anchors ranged from " 1 " (not at all involved) to "7” (fully involved).

\section{Prospector/defender business strategy}

The measure developed by Shortell and Zajac (1990) was used. This instrument assesses an organization's overall strategic orientation on a seven-point scale, anchored at one 
end by a description of a defender-type organization, and at the other end by a prospector-type organization.

\section{Deliberate strategy formulation orientation}

Because this dimension of strategy has not been operationalized in any known previous work, an original measurement instrument had to be developed. In order to assess an organization's extent of deliberate strategy formulation orientation, three statements were provided to respondents. Drawing on Mintzberg's (1987a) terminology, these statements were: (1) "In our company, the strategic decision-makers usually think through everything in advance of strategic action" (2) "In our company, strategic intentions are seldom realized with little or no deviation", and (3) "In our company, strategic action usually develops in the absence of strategic intention". Next to each statement, a seven-point scale was provided, ranging from " 1 " (strongly disagree) to "7" (strongly agree).

\section{Market orientation}

Market orientation was measured using the same instrument applied by Guilding and McManus (2002). Using a seven-point scale ranging from " 1 ” (not at all) to "7" (to a large extent) respondents were asked to indicate to what extent they agree with the following statements: “(1) My company has a strong understanding of our customers, (2) the functions in my company work closely together to create superior value for our customers, (3) management in my organization thinks in terms of serving the needs and wants of well-defined markets chosen for their long-term growth and profit potential for the company, and (4) my company has a strong market orientation”.

\section{Company size}

Total revenues were used as the measure of company size. Due to the non-normality of the raw data collected, logarithmic transformation was undertaken prior to the analysis.

\section{Performance}

Performance was measured using a slightly modified version of the Hoque and James (2000) instrument. Two additional dimensions have been added to Hoque and James' five dimensions of performance. The original dimensions comprise: (1) return on investment, (2) margin on sales, (3) capacity utilization, (4) customer satisfaction, and (5) product quality. The two additional dimensions are (6) development of new products, and (7) market share. For each of these seven dimensions, respondents were asked to indicate their company's performance relative to their competitors on a scale ranging from " 1 ” (below average) to "7” (above average).

\subsection{Data analysis}

In order to test the proposed contingency model, the LISREL structural equation modelling procedure was applied. This statistical technique allows for the simultaneous estimation of multiple and interrelated dependence relationships, has the ability to represent unobservable concepts, and accounts for the measurement error in the estimation process (Hair et al, 1998; Ferligoj et al, 2003; O’Connor et al, 2006). Smith and Langfield-Smith (2004) advocate that SEM is particularly appropriate for modelling 
relations between environment, strategy, and organizational structure, because theory in this area is relatively established and a considerable body of knowledge exists.

Following the recommended two-step approach (Anderson and Gerbing, 1988; Joreskog and Sorbom, 1993; Schumacker and Lomax, 1996; Hair et al, 1998; Ferligoj et al, 2003), firstly the measurement model was tested, then the structural model. The measurement model is concerned with the measurement properties (validities and reliabilities) of the measurement instruments, while the structural model is concerned with causal relationships among the constructs and their relative explanatory power (Joreskog and Sorbom, 1993).

In the model specification process, particular attention was given to the potential for multi-dimensionality in two of the constructs: SMA usage and performance. Prior to testing the overall contingency model, on theoretical grounds and also in light of factor analytic observations, the dimensionality of these two constructs was given due consideration (Gerbing and Hamilton, 1996). The comparison of alternative factor structure models (Joreskog and Sorbom, 1993; Byrne, 1998) revealed that best model fit is achieved when SMA usage is specified as a five-factor structure and when performance is specified as a two-factor structure. It is notable that others have viewed performance as a two-dimensional construct comprising financial and non-financial performance (Kaplan and Norton, 1992; 1996; Chenhall, 2005).

Because the primary goal was to estimate relationships between constructs while increasing the estimation model parsimony, a partial aggregation approach (Bagozzi and Edwards, 1998) was taken to represent multi-dimensional constructs. ${ }^{3}$ This means that each dimension was represented in the model with a variable that was calculated as an average of the retained original indicators. For example, for the costing dimension of the SMA usage construct, one composite item was calculated as the mean of five original items.

\section{FINDINGS}

\subsection{Structural equation model}

A priori reasoning suggested that SMA usage is a five-dimensional construct (see Table 1) and performance is a two-dimensional construct. Based on the premise that exploratory factor analysis can contribute to a useful heuristic strategy for model specification prior to cross-validation with confirmatory factor analysis (Gerbing and Hamilton, 1996), both exploratory and confirmatory factor analyses (first and secondorder) were conducted. The results confirmed that best model fit results when SMA

\footnotetext{
${ }^{3}$ The SMA techniques and performance dimensions were consolidated into underlying factors to increase the model's parsimony. As an investigation of the reliability of the reported model, an analysis of a second-order factor model incorporating all of the individual SMA technique adoption measures was conducted. This yielded parameters identical to those in the reported model, however the second-order factor model should be viewed as potentially unstable, as the ratio of observations per estimated parameter is below 3 .
} 
usage is specified as comprising five factors and performance is specified as two factors. Consistent with Table 1, the five dimensions of SMA usage have been labelled: (1) costing, (2) planning, control, and performance measurement, (3) strategic-decision making, (4) competitor accounting, and (5) customer accounting. The two dimensions of performance have been labelled: (1) financial performance, and (2) non-financial performance.

Using the partial aggregation approach for the two multi-dimensional constructs, the total number of indicators entering the measurement model is 21. The number of indicators per construct is: SMA usage: 5 (i.e., the 16 techniques were collapsed into 5 SMA dimensions by calculating composite items); accountant's participation in strategic decision making: 5; business strategy: 1; strategy deliberation: 3; market orientation: 4; company size: 1; and performance: 2 (7 questionnaire items were collapsed into 2 main dimensions). Constructs measured with only 1 indicator are problematic, because it is impossible to empirically estimate their reliability. For these constructs, one can either assume there is no measurement error, or a reliability value for a single measure must be specified (Anderson and Gerbing, 1988; Schumacker and Lomax, 1996; Hair et al, 1998). Total revenues as an indicator of company size is an objective measure obtained from a credible source, thus minimal measurement error can be assumed. The measure of business strategy is, however, not objective and it is unreasonable to assume no error variance (Joreskog and Sorbom, 1993). Because of this, in light of arguments that an arbitrary value of 0.8 is a better assumption than an equally arbitrary value of 1 (Joreskog and Sorbom, 1993; Schumacker and Lomax, 1996), it has been assumed that the reliability of business strategy is 0.8 .

To estimate the measurement model, the maximum likelihood estimation method was used. Input data was provided in the form of a variance-covariance matrix, supplemented with the asymptotic covariance matrix (Schumacker and Lomax, 1996). An initial estimate revealed a problem requiring a respecification of the model. The problem was a very high correlation (0.9) between two of the participation in strategic decision making items (evaluating options and developing details about options) and this was resolved by dropping the latter from the model. The respecified model fitted the data quite well with all major indices $(\mathrm{NFI}=0.938$, NNFI $=0.970$, CFI $=0.976$; SRMR $=0.054$, RMSEA $=0.042$ ) falling within acceptable levels (Schumacker and Lomax, 1996; Hair et al, 1998; Lance and Vandenberg, 2002) and with standardized residuals symmetrically clustered around the zero point (Joreskog and Sorbom, 1993; Byrne, 1998). All of the factor loadings exceeded 0.5 and were statistically significant at $p<$ 0.01 level. Taking these factors into account, it was determined that the measurement model holds and the analysis progressed to testing the structural model.

Prior to reporting the structural model testing results, the correlation levels between constructs in the measurement model are presented in Table 4 . Of the 21 relationships reported on in this table, 18 are positively statistically significant $(p<0.05)$. Given the confirmatory nature of the study, of greatest interest is the 11 hypothesized relationships (these correlations are highlighted in bold in Table 4). All 11 correlations are statistically significant and consistent with what was hypothesized. A very high correlation is evident between the application of a prospector strategy and performance. 
This relationship was not hypothesized in the theoretical model. The finding is surprising as it contradicts Miles and Snow's (1978) premise that both the prospector and defender archetypes are ideal organizational strategies.

\section{INSERT TABLE 4 ABOUT HERE}

The results of the structural model are presented in Figure 2. In this figure, only "structural" parameters (regression coefficients and $\mathrm{R}^{2}$ values) are presented. These findings signify support for 9 of the 11 hypothesized relationships. Accountants' participation in strategic decision making is positively associated with prospector strategy and deliberate strategy (however these contingent factors only explain 13\% of the participation variance). SMA usage is positively associated with three of the four contingent factors (prospector strategy, deliberate strategy, and company size), and also accountants' participation in strategy (explaining 62\% of the variation in SMA usage). With respect to the relationship between SMA and performance, SMA usage exhibits a statistically significant positive relationship, while strategic decision making participation is not significantly related to performance. Performance is also directly influenced by a contingent factor market orientation. In combination, the variables appraised explain $71 \%$ of the variation of performance.

\section{INSERT FIGURE 2 ABOUT HERE}

The hypothesised relationships that have not been supported by the model also appear worthy of comment. The structural model indicates that SMA usage is not associated with market orientation, although in the measurement model there is a relatively strong correlation between the two constructs. This can be explained by the very strong direct relationship between market orientation and performance which undermines the indirect effect via SMA usage. It is also interesting that strategic decision making participation does not directly influence performance, however an indirect effect exists between participation and performance via SMA usage.

From a holistic perspective, the model is dominated by a very strong direct effect of market orientation on performance. This dominant relationship may have contributed to the mediating (intervening) effect of SMA system being somewhat lower than anticipated. Despite this, a significant mediating effect of SMA system on performance is evident. SMA usage is positively affected by the adoption of a prospector strategy and a deliberate approach to strategy formulation (both directly and indirectly via participation), and company size, while SMA usage, in turn, positively affects performance. The results therefore largely support the central proposition of contingency theory asserting that organizational performance depends on fit between organizational context and structure. The relatively large proportion of explained variance for SMA usage and performance also indicates that the identified contingent factors are indeed 
relevant to the model, although participation in strategic decision making is apparently affected by factors not captured in this study.

As is evident from the discussion provided above, structural modelling necessitates the exercise of a degree of subjectivity. The correlation analysis conducted (Table 4) revealed an unhypothesised highly positive relationship between performance and the prospector strategic archetype, despite Miles and Snow's view that prospectors as well as defenders represent ideal strategic types (see also Smith et al, 1989). Following this observation, and inspite of the position taken by Miles and Snow, an investigation of the robustness of the model depicted in Figure 2 was conducted by incorporating a direct path between "strategy type" and "performance". This revised model revealed a significant association between "strategy type" and "performance" (coefficient 0.34, $p<$ 0.01). The probability level of all other statistical relationships recorded in Figure 2 were unaltered with the exception that the path linking market orientation and SMA usage became marginally significant ( $p<0.05$ : two tail) and the path linking SMA usage and performance became marginally insignificant. While these two paths have moved in opposite ways across the threshold of significance, the absolute size of the coefficient change for both is relatively minor. This investigation therefore suggests a reasonable degree of robustness for the model depicted in Figure 2.

\subsection{Interviews}

The interviews comprised two phases. During the first phase, interviewees were asked to express their opinions on what factors might affect SMA adoption in Slovenian companies and also which industries are likely to have a higher incidence of SMA adoption. In phase two, the interviewees were presented with the structural equation model findings and asked to comment on the validity of the findings with respect to factors affecting SMA usage.

The most widely noted organizational factor affecting SMA adoption was corporate or business strategy (cited by eight of the ten interviewees). The second most widely cited factor was the intensity of competition (referred to by five interviewees), suggesting greater SMA usage may be associated with heightened competiton. Management accounting capability was referred to by five interviewees (three of whom referred to the capability of accountants and two of whom referred to information system capabilities). It was notable that only one of the interviewees referred to company size as a factor affecting SMA adoption. The comments provided by interviewees $G, A$, and $F$ were especially insightful:

"I think that the most important factor is coporate strategy. Our company has traditionally been a producer of basic construction materials (e.g. cement) with relatively low value added. Eventually, some time ago we decided to change our strategic focus by moving up the value chain to offer construction products with greater value added (e.g. concrete). This strategy proved to be a success... During this process, we have used some techniques that you also list here... But the techniques we find more valuable today are different than the techniques we found valuable in the past...”. 
"Strategy is an important factor affecting the use of these techniques. However things are not so straightforward in a company such as ours where the profit motive is not prevalent. These techniques are about improving efficiency. Yet in our company, due to great power of trade unions, rationalizations, especially if they result in redundancy, are often unwelcome. In our company, the spirit of socialism is still present...”.

"We need to provide information that the management requires. An important factor affecting their requirements is strategy. Based on these requirements, we adopt appropriate methods in order to provide the information in a format most apt for the users".

All of the interviewees expressed the view that the applicability of SMA is industry specific. Despite this, limited consensus was apparent with respect to what particular industrial sector characteristics are conducive to SMA application. Amongst the industry factors noted as conducive to SMA application were: high degrees of competition, manufacturing, high degrees of regulation and resource scarcity.

The face validity of the statistically significant association between the four contingent factors and SMA adoption noted in Figure 2 was then commented on by the interviewees. With respect to the positive association between prospector strategy and greater SMA usage, the interviewees agreed unanimously that this association carries high intuitive appeal. Some felt that prospectors' quest for new business opportunities predisposed them towards innovating in all areas of business, including the adoption of novel accounting techniques. Some also saw the application of externally oriented SMA techniques as providing important decision making information for the successul application of an externally focused prospector strategy. For example, Interviewee $\mathrm{C}$ commented:

"A prospector company is always a step ahead in a quest for new market opportunities and this business culture is adaptable to all areas of making business. Employees in prospector type firms in general have a wider horizon and are more prone to accept innovative approaches, including novel accounting techniques".

Figure 2's documented positive association between deliberate strategy and greater SMA usage was also seen to represent a highly rational observation by all of the interviewees. They saw accounting techniques with a strategic orientation as providing important support to strategy formulation in firms applying formalised approaches to strategy determination and implementation. For instance, Interviewee I commented:

"Deliberate strategy is about planning. In our company profitability is a key objective. In order to achieve planned profitability, knowledge about the market is essential. We need to know as much as possible about our competitors and our customers in order to plan effectively". 
The interviewees also exhibited strong support for the positive association between company size and greater SMA usage (with the exception of interviewee J who saw no particular reason for any relationship between size and SMA usage). Several claimed that increased company size signifies increased complexity and a greater call for sophisticated accounting procedures to manage the complexity. Some also commented that increased company size is associated with greater resources (human, financial, and technical), while others noted that the cost of information processing per unit of output declines as company size increases.

The interviewees' perspectives on whether market orientation carries an implication for SMA usage were somewhat mixed. Five interviewees expressed surprise at the failure to identify a positive relationship between the two variables. For example, Interviewee E commented:

"I am surprised by this finding. Even if the company is completely market orientated, i.e., it would do everything to satisfy the customer, it still needs information about how far it can go. If I do everything for my customer for free then I haven’t done anything for myself”.

The other five interviewees did not see a strong rationale for a positive relationship between market orientation and SMA usage. The following commentaries were provided by interviewees $\mathrm{C}, \mathrm{G}$, and $\mathrm{J}$ :

"If the customer is fully satisfied, he is also prepared to pay a high price. In this case, there is no need for detailed analyses”.

"The SMA techniques do not represent tools that search for new customers. Sales is much like prostitution. We need to deliver whatever our customers want and our customers mainly want low price. So that's what we deliver".

"In the past socialist times, all companies including ours were production oriented. First we manufactured, then we worried about selling what we have manufactured. It is only recently that we have started emphasizing market orientation. Now we first turn to customer needs and then we adjust our offerings accordingly in order to secure profitability. This is a sign of company maturity".

As a final interview step, interviewees were asked to rank the relative importance of a list of six contingent factors (drawn from the literature) that may influence SMA usage. This list comprised: company size, environmental uncertainty, intensity of competition, organizational culture, stage of the product life cycle, and strategy. In a manner strongly aligning with what has already been reported in this section, strategy ranked most highly (four interviewees ranked it as 1 and four ranked it as 2), followed closely by intensity of competition (four interviewees ranked it as 1 and one ranked it as 2).

\section{CONCLUSION}


This study provides several contributions. Firstly, it provides a conceptual representation of strategic management accounting's context that extends prior SMA commentaries. Secondly, it draws on quantitative and qualitative empirical data to examine contingency theory based hypotheses concerning SMA. The findings provide support for contingency theory's central proposition that organizational performance depends on the fit between organizational context and structure.

More than a decade has passed since Tomkins and Carr (1996) noted that no generally accepted SMA framework exists. This view may no longer be quite so tenable. In this study two distinct dimensions of SMA have been noted. The first draws on prior studies (Guilding et al, 2000; Cravens and Guilding, 2001; Roslender and Hart, 2003) by viewing SMA as a set of strategically-oriented management accounting techniques. The second SMA perspective represents a relatively novel slant on the accountant's role in strategy. It draws on recent commentaries suggesting that strategic management accountants are no longer just information providers, rather they can participate as an integral influence in the strategic decision-making team (Palmer, 1992; Bhimani and Keshtvarz, 1999; Scott and Tiessen, 1999; Nyamori et al, 2001).

This study's focus on the organizational context of SMA can be seen as consistent with calls to maintain research relevancy through the examination of novel management practices within contemporary settings (Ittner and Larcker, 2001; Chenhall, 2003). By drawing on the premises of contingency theory, four factors were identified as potentially exhibiting a contingency relationship with SMA. These are (1) business strategy, (2) deliberate strategy formulation orientation, (3) market orientation and (4) firm size.

The findings emanating from the structural model provide support for most of the hypothesised relationships. Accountants' strategic decision making participation is positively associated with the application of a prospector strategy and also deliberate strategy formulation. SMA usage is positively associated with adopting a prospector strategy, deliberate strategy formulation, company size, and accountants' strategic decision making participation. SMA usage, in turn, also positively affects performance. Given that in a structural equation model fit is depicted as a statistically significant indirect effect (Gerdin and Greve, 2004), these results provide support for the contingency theory premise. In addition, the relatively large proportion of explained variance for SMA usage and performance indicates that the identified contingent factors are pertinent to the SMA organizational framework.

The qualitative interview data findings lend considerable validity to the conclusions drawn from the quantitative analysis and also yielded some additional insights. With respect to the identification of significant contingency factors, there was nigh on unanimous interviewee concurrence that strategy is the most important factor affecting SMA usage. In addition, another potentially important factor was uncovered, namely the intensity of competition (a factor that was not incorporated in the quantitatively examined model). While the interviewees saw considerable face validity in the statistically significant findings emanating from the study's survey phase, equivocality is evident with respect to the hypothesized relationship between market orientation and 
SMA usage. While no quantitative support was found for this hypothesis, the mixed reactions of the interviewees suggest it might be premature to abandon market orientation from any subsequent research into factors relating to SMA adoption.

Considered holistically, the findings provide support for the application of contingency theory in accounting system design. They signify that the application of SMA systems are not necessarily related to superior performance, but that superior performance is a product of an appropriate match between contingent factors and SMA application. There is, however, universal support provided for the view that higher performance is found in large Slovenian companies with a high market orientation. This supports the claim by Slater and Narver (1994, p.54), that "being market oriented can never be a negative".

As contingent management accounting research is often criticized for the piecemental way in which it is conducted (Fisher, 1995; Chenhall and Langfield-Smith, 1998b), this study clearly contributes to our limited appreciation of the way in which strategic and marketing choices and SMA practices combine to enhance performance. If the ultimate goal of contingency-based management accounting research is to test a comprehensive model that includes multiple accounting systems, multiple contingent variables, and multiple outcome variables (Fisher, 1995), this study would appear to constitute a step in the desired direction.

Given the still nascent nature of SMA, it is to be expected that further conceptions of what it constitutes may be forthcoming. In fact the challenge of distilling a tight operationalisation of the term 'strategic management accounting' is likely to be an enduring facet of research associated with the term. This is because not only is there limited consensus in the literature with respect to the meaning of the word 'strategy', there is also limited consensus with respect to what management techniques constitute management accounting (Bromwich, 1988). Despite this, there does appear to be broad consensus that strategy concerns an organizational posture that is long term, forward looking and externally focused.

It is notable that the SMA practices examined in this study all represent relatively recently conceived accounting techniques. None of them feature in normative management accounting discourse undertaken prior to the 1980s. It appears as no coincidence that the burgeoning interest in these relatively strategically oriented accounting techniques occurred around the time that the term 'strategic management accounting' was first coined by Simmonds (1981). The somewhat contemporaneous nature of these developments signify that the techniques are likely to be viewed in many organizations as relatively marginal, suggesting that accountants are likely to exercise a high degree of discretion when determining whether they be adopted. This marginality is believed to have been a facilitating factor in this study, as degree of adoption of the techniques represents a useful barometer, with scope for variability, in measuring a firm's relative propensity to adopt strategically oriented management accounting practices. Despite this, it should be acknowledged that some conventional management accounting practices may be interpreted as having strategically oriented qualities, and in further research that conceives of SMA in a manner similar to that adopted in this study, 
consideration could be given to their inclusion in the strategic management accounting rubric.

The study can be considered noteworthy in terms of methodology employed. Following the call by Ittner and Larcker (2001) to deploy multiple data sources or research models to develop a consistent body of evidence, this study has applied two distinct approaches to data collection: the acquisition of quantitative data by way of a survey and qualitative data collected by way of interviews. The deployment of intervening models based on structural equation modelling in contingency-based research has not been extensively applied (e.g., Chong and Chong, 1997; Scott and Tiesen, 1999; Shields et al, 2000; Baines and Langfield-Smith, 2003; Chenhall, 2005), however, when this approach is coupled to the collection of qualitative data, the novelty of the methodology applied in this study becomes particularly apparent. It should be noted, however, that the application of the interview method in a way that calls for interviewees to pass comment on the face validity of prior survey findings is likely to be compromised by the halo effect. While careful consideration needs to be given to this shortcoming, the conduct of "post survey" interviews in this study has proven to be a useful approach that has yielded greater insight into the phenomenon under examination.

The study can also be seen as constituting an overdue enquiry into the validity of viewing "strategic management accounting" as a coherent empirical construct. By placing strategic management accounting techniques in a contingency model and conducting an empirically based examination of the model, an advancement has been made in our appreciation of the extent to which strategic management accounting constitutes a construct that is sufficiently robust to enable empirical analysis. Despite the considerable discourse on strategic management accounting occurring since the early 1980s (e.g., Bromwich, 1990; Guilding et al, 2000; Roslender and Hart, 2003) very little has been achieved in terms of empirical enquiry designed to further our appreciation of the nature and context of SMA application. The extent to which the hypotheses formulated in this study have received empirical support provides affirmation that SMA can be investigated as a cohesive construct in a meaningful way.

In interpreting the study's findings, its limitations should be borne in mind. Firstly, while the proposed model is relatively complex in terms of the number of contingency factors under consideration, it is nevertheless incomplete as there are doubtlessly other significant contingency factors that have not been captured in the model tested. Some factors that have been examined in relation to firm-level management accounting practices include intensity of competition, environmental uncertainty, technology, structure, and organizational culture (Anderson and Lanen, 1999; Chenhall, 2003). These factors would appear to be prime candidates for inclusion in any study designed to extend the findings reported here, particularly "competition intensity", given commentaries provided by this study's interviewees. Secondly, a shortcoming of the study stems from the use of a single item measure of business strategy. The use of single item measures precludes any investigation of construct reliability. Given the confirmatory orientation of the study, it is also noteworthy that two expected relationships were not confirmed. This might be due to conflicting contingencies (Gerdin, 2005), and also the attempt to explain strategic management accounting in the 
context of strategy and marketing, even though strategy is itself often characterized by an ambiguous and contradictory nature (Mintzberg, 1987a; 1987b).

In addition to these study specific limitations, there are other issues associated with contingency-based research in general. One particular issue revolves around the endogeneity problem arising when a researcher seeks to appraise whether a particular management accounting practice or action is associated with performance (Ittner and Larcker, 2001; Chenhall, 2003; Chenhall and Moers, 2007). The model specified in this study assumes that disequilibrium conditions exist, signifying an assumption that the optimal level of SMA adoption will vary across organizations. Further, while many different forms of fit have been used in the past, very few researchers acknowledge the problems of relating them to one another (Gerdin and Greve, 2004). For example, Drazin and Van de Ven (1985) and Selto et al (1995) contend that the selection, interaction, and systems approaches provide complementary information and in their studies deploy all three approaches on the same data set. Countering this view, Gerdin and Greve (2004) argue that the approaches are paradigmatically different. At the top level of the hierarchical structure that they propose, they see the cartesian (reductionist) and configuration (holistic) approaches as constituting two conflicting paradigms and feel it inappropriate to relate results emanating from cartesian modelling to results yielded by configuration modelling. As a result, some researchers claim that their findings are conflicting, when this is not necessarily the case, while others inappropriately claim that their observations are supported by previous studies.

These factors need to be born in mind when attempting to build on the findings reported herein. This is an important consideration, for while this study is believed to constitute one of the most extensive SMA contingency models formulated to date, it is doubtlessly incomplete. Further research that develops and tests hypotheses concerning factors relating to SMA adoption is to be encouraged as we are little beyond a preliminary stage in the process of developing a robust theory of the context and impact of SMA. Following the rationale presented by Ittner and Larcker (2001) and Chenhall (2003), further attempts to advance this theory would likely benefit from operationalising performance in terms of espoused strategy. 


\section{APPENDIX: Glossary of terms, provided to respondents}

\section{Attribute costing}

The costing of specific product attributes that appeal to customers. Attributes that may be costed include: operating performance variables; reliability, warranty arrangements; the degree of finish and trim; assurance of supply; and after sales service.

\section{Benchmarking}

The comparison of internal processes to an ideal standard.

\section{Brand valuation}

The financial valuation of a brand through the assessment of brand strength factors such as: leadership, stability, market, internationality, trend, support, and protection combined with historical brand profits.

\section{Competitor cost assessment}

The provision of regularly scheduled update estimate of a competitor's unit cost.

\section{Competitive position monitoring}

The analysis of competitor positions within the industry by assessing and monitoring trends in competitor sales, market share, volume, unit costs, and return on sales. This information can provide a basis for the assessment of a competitor's market strategy.

\section{Competitor performance appraisal}

The numerical analysis of a competitor's published statements as a part of an assessment of a competitor's key sources of competitive advantage.

\section{Customer profitability analysis}

This involves calculating profit earned from a specific customer. The profit calculation is based on costs and sales that can be traced to a particular customer. This technique is sometimes referred to as "customer account profitability".

\section{Integrated performance measurement}

A measurement system which focuses typically on acquiring performance knowledge based on customer requirements and may encompass non-financial measures. This measure involves departments monitoring those factors which are critical to securing customer satisfaction.

\section{Life cycle costing}

The appraisal of costs based on the length of stages of a product or service's life. These stages may include design, introduction, growth, maturity, decline and eventually abandonment. 


\section{Lifetime customer profitability analysis}

This involves extending the time horizon for customer profitability analysis to include future years. The practice focuses on all anticipated future revenue streams and costs involved in servicing a particular customer.

\section{Quality costing}

Quality costs are those costs associated with the creation, identification, repair and prevention of defects. These can be classified into three categories: prevention, appraisal, and internal and external failure costs. Cost of quality reports are produced for the purpose of directing management attention to prioritize quality problems.

\section{Strategic costing (strategic cost management)}

The use of cost data based on strategic and marketing information to develop and identify superior strategies that will produce a sustainable competitive advantage.

\section{Strategic pricing}

The analysis of strategic factors in the pricing decision process. These factors may include: competitor price reaction, elasticity, market growth, economies of scale, and experience.

\section{Target costing}

A method used during product and process design that involves estimating a cost calculated by subtracting a desired profit margin from an estimated (or market-based) price to arrive at a desired production, engineering, or marketing cost. The product is then designed to meet that cost.

\section{Valuation of customers as assets}

The technique refers to the calculation of the value of customers to the company. For example, this could be undertaken by computing the present value of all future profit streams attributable to a particular customer.

\section{Value chain costing}

An activity-based approach where costs are allocated to activities required to design, procure, produce, market, distribute, and service a product or service. 


\section{REFERENCES}

Abernethy, M. A., \& Guthrie, C. H. (1994). An empirical assessment of the "fit" between strategy and management information system design. Accounting and Finance, 34, 49-66.

Abernethy, M. A., \& Brownell, P. (1999). The role of budgets in organizations facing strategic change: an exploratory study. Accounting, Organizations and Society, 24, 189204.

Abernethy, M. A., \& Bouwens, J. (2005). Determinants of accounting innovation implementation. Abacus, 41, 217-239.

Agbejule, A. (2005). The relationship between management accounting systems and perceived environmental uncertainty on managerial performance: a research note. Accounting and Business Research, 35, 295-305.

Anderson, J. C., \& Gerbing, D. W. (1988). Structural equation modeling in practice: a review and recommended two-step approach. Psychological Bulletin, 103, 411-423.

Anderson, S. W., \& Lanen, W. N. (1999). Economic transition, strategy and the evolution of management accounting practices. Accounting, Organizations and Society, 24, 379-412.

Andrews, K. R. (1987). The concept of corporate strategy. Homewood: Irwin.

Ashton, D., Hopper, T., \& Scapens, R. W. (1991). Introduction. In D. Ashton, T. Hopper, \& R. W. Scapens (Eds.), Issues in Management Accounting. New York: Prentice Hall.

Bagozzi, R. P., \& Edwards, J. R. (1998). A general approach for representing constructs in organizational research. Organizational Research Methods, 1, 45-187.

Baines, A., \& Langfield-Smith, K. (2003). Antecedents to management accounting change: a structural equation approach. Accounting, Organizations and Society, 28, 675698.

Bellis-Jones, R. (1989). Customer profitability analysis. Management Accounting, 63, 26-28.

Belohlav, J. A. (1993). Quality, strategy and competitiveness. Califonia Management Review, 35, 55-67.

Bhimani, A., \& Bromwich, M. (1992). Management accounting: evolution in progress. In C. Drury (Ed.), Management Accounting Handbook. Oxford: Butterworth-Heineman. 
Bhimani, A., \& Keshtvarz, M. H. (1999). British management accountants: strategically oriented. Journal of Cost Management, 13, 25-31.

Bhimani, A. and Langfield-Smith, K. (2007). Structure, formality and the importance of financial and non-financial information in strategy development and implementation. Management Accounting Research, 18, 3-31.

Bogel, G., \& Huszty, A. S. (1999). Transition to market economy as inflection point: can strategy help?. Business Horizons, 42, 7-13.

Bromwich, M. (1988). Managerial accounting definition and scope - from a managerial view. Management Accounting, 66, 26-27.

Bromwich, M. (1990). The case for strategic management accounting: the role of accounting information for strategy in competitive markets. Accounting, Organizations and Society, 15, 27-46.

Bromwich, M. (1992). Strategic management accounting. In C. Drury (Ed.), Management Accounting Handbook. Oxford: Butterworth-Heinemann.

Bromwich, M. (2000). Thoughts on management accounting and strategy. Pacific Accounting Review, 11, 41-48.

Brouthers, K., \& Roozen, F. (1999). Is it time to start thinking about strategic accounting?. Long Range Planning, 32, 311-322.

Brownlie, D. (1999). Benchmarking your marketing process. Long Range Planning, 31, 88-95.

Bruggeman, W., \& Van der Stede, W. (1993). Fitting management control systems to competitive advantage. British Journal of Management, 4, 205-218.

Byrne, B. M. (1998). Structural equation modelling with LISREL, PRELIS, and SIMPLIS: basic concepts, applications, and programming. Mahwah: Lawrence Erlbaum Associates.

Cadez, S. (2002). Strategic management accounting: conceptual framework and empirical evidence from Slovenian companies. Economic and Business Review, 4, 129157.

Cadez, S., \& Guilding, C. (2007). Benchmarking the incidence of strategic management accounting in Slovenia. Journal of Accounting and Organizational Change, 3, 126-146.

Carr, C., \& Tomkins, C. (1996). Strategic investment decisions: the importance of SCM. A comparative analysis of 51 case studies in U.K., U.S. and German companies. Management Accounting Research, 7, 199-217. 
Chenhall, R. H. (1997). Reliance on manufacturing performance measures, total quality management and organizational performance. Management Accounting Research, 8, 187-206.

Chenhall, R. H. (2003). Management control systems design within its organizational context: findings from contingency-based research and directions for the future. Accounting, Organizations and Society, 28, 127-168.

Chenhall, R. H. (2005). Integrative strategic performance measurement systems, strategic alignment of manufacturing, learning and strategic outcomes: an exploratory study. Accounting, Organizations and Society, 30, 395-422.

Chenhall, R. H. (2007). Theorising Contingencies in Management Control Systems Research, pp. 163-205 in C. Chapman, A. Hopwood, and M. Shields, (Eds) Handbook of Management Accounting Research, Oxford: Elsevier.

Chenhall, R. H. (in press). Accounting for the horizontal organization: a review essay. Accounting, Organizations and Society.

Chenhall, R. H., \& Langfield-Smith, K (1998a). Factors influencing the role of management accounting in the development of performance measures within organizational change programs. Management Accounting Research, 9, 361-386.

Chenhall, R. H., \& Langfield-Smith, K. (1998b). The relationship between strategic priorities, management techniques and management accounting: an empirical investigation using a systems approach. Accounting, Organizations and Society, 23, 243-264.

Chenhall, R. H., \& Langfield-Smith, K. (2003). Performance measurement and reward systems, trust, and strategic change. Journal of Management Accounting Research, 15, 117-143.

Chenhall, R. H., \& Moers, F. (2007). The issue of endogeneity within theory-based, quantitative management accounting research. European Accounting Review, 16, 173195.

Chenhall, R. H., \& Morris, D. (1986). The impact of structure, environment and interdependence on the perceived usefulness of management accounting systems. The Accounting Review, 61, 16-35.

Chong, V. K., \& Chong, K. M. (1997). Strategic choices, Environmental uncertainty and SBU performance: a note on the intervening role of management accounting systems. Accounting and Business Research, 27, 268-276.

Chong, V. K., \& Johnson, D. M. (2007). Testing a model of the antecedents and consequences of budgetary participation on job performance. Accounting and Business Research, 37, 3-19. 
Chow, C. W., Shields, M. D., \& Wu, A. (1999). The importance of national culture in the design of and preference for management controls for multi-national operations. Accounting, Organizations and Society, 24, 441-461.

Christensen, P. O., \& Demski, J. S. (2003). Accounting theory; an information content perspective. Boston: McGraw-Hill.

Christensen, P. O., \& Feltham, G. A. (2003). Economics of accounting: volume I Information in markets. Boston: Kluwer academic publishers.

Clinton, D. B., \& Hunton, J. E. (2001). Linking participative budgeting congruence to organizational performance. Behavioral Research in Accounting, 13, 127-140.

Coad, A. (1996). Smart work and hard work: explicating a learning orientation in strategic management accounting. Management Accounting Research, 7, 387-408.

Cooper, R., \& Slagmulder, R. (1999). Develop profitable new products with target costing. Sloan Management Review, 40, 23-33.

Cravens, K. S., \& Guilding, C. (1999). Strategic brand valuation: a cross-functional perspective. Business Horizons, 42, 53-62.

Cravens, K. S., \& Guilding, C. (2001). An empirical study of the application of strategic management accounting techniques. Advances in Management Accounting, 10, 95-124.

Czyzewski, A. B., \& Hull, R. (1991). Improving profitability with life cycle costing. Journal of Cost Management, 5, 20-27.

Davila, T. (2000). An empirical study on the drivers of management control system's design in new product development. Accounting, Organizations and Society, 25, 383409.

De Haas, M., \& Algera, J. A. (2002). Demonstrating the effect of the strategic dialogue: participation in designing the management control system. Management Accounting Research, 13, 41-69.

De Haas, M., \& Kleingeld, A. (1999). Multilevel design of performance measurement systems: enhancing strategic dialogue throughout the organization. Management Accounting Research, 10, 233-261.

Dekker, H. C. (2003). Value chain analysis in interfirm relationships: a field study. Management Accounting Research, 14, 1-23.

Dent, J. F. (1990). Strategy, organization and control: some possibilities for accounting research. Accounting, Organizations and Society, 15, 3-25. 
Dixon, R. (1998). Accounting for strategic management: a practical application. Long Range Planning, 31, 272-279.

Doty, H. D., Glick, W. H., \& Huber, G. P. (1993). Fit, equifinality, and organizational effectiveness: a test of two configurational theories. Academy of Management Journal, 36, 1196-1250.

Drazin, R., \& Van De Ven, A. (1985). Alternative forms of fit in contingency theory. Administrative Science Quarterly, 30, 514-540.

Drury, C. (1992). Introduction. In C. Drury (Ed.), Management Accounting Handbook. Oxford: Butterworth-Heinemann.

Dunk, A. S. (2004). Product life cycle cost analysis: the impact of customer profiling, competitive advantage, and quality of IS information. Management Accounting Research, 15, 401-414.

Edwards, V., \& Lawrence, P. A. (2000). Management in Eastern Europe. Basingstoke: Macmillan.

Elnathan, D., Lin, T. W., \& Young, M. S. (1996). Benchmarking and management accounting: a framework for research. Journal of Management Accounting Research, 8, 37-54.

Ferligoj, A., Omladic, V., \& Coenders, G. (2003). Multivariate analysis: structural equation models (SEM). Ljubljana: University of Ljubljana.

Fern, R. H., \& Tipgos, M. A. (1988). Controlers as business strategists: a progress report. Management Accounting, 69, 25-29.

Fisher, J. (1995). Contingency-based research on management control systems: categorization by level of complexity. Journal of Accounting Literature, 14, 24-53.

Fisher, C. (1996). The impact of perceived environmental uncertainty and individual differences on management information requirements: a research note. Accounting, Organizations and Society, 21, 361-369.

Foster, G., \& Gupta, M. (1994). Marketing, cost management and management accounting. Journal of Management Accounting Research, 6, 43-77.

Foster, G., Gupta, M., \& Sjoblom, L. (1996). Customer profitability analysis: challenges and new directions. Journal of Cost Management, 10, 5-17.

Gelinas, U. J., Sutton, S. G., \& Oram A. E. (1998). Accounting information systems (4th ed.). Cincinatti: South-Western College Publishing.

Gerbing, D. W., \& Hamilton, J. G. (1996). Viability of exploratory factor analysis as a 
precursor to confirmatory factor analysis. Structural Equation Modeling, 3, 62-72.

Gerdin, J., \& Greve, J. (2004). Forms of contingency fit in management accounting research-a critical review. Accounting, Organizations and Society, 29, 303-326.

Gerdin, J. (2005). Management accounting system design in manufacturing departments: an empirical investigation using a multiple contingencies approach. Accounting, Organizations and Society, 30, 99-126.

Ginzberg, M. J. (1980). An organizational contingencies view of accounting and information systems implementation. Accounting, Organizations and Society, 5, 369382.

Gordon, L. A., \& Miller, D. (1976). A contingency framework for the design of accounting informations systems. Accounting, Organizations and Society, 1, 59-69.

Gordon, L. A., \& Narayanan, V. K. (1984). Management accounting systems, perceived environmental uncertainty and organization structure: an empirical investigation. Accounting, Organizations and Society, 9, 33-47.

Govindarajan, V., \& Gupta, A. K. (1985). Linking control systems to business unit strategy: impact on performance. Accounting, Organizations and Society, 10, 51-66.

Guilding, C. (1992). Should management accounting take up the brand valuation challenge?. Management Accounting, 70, 44-46.

Guilding, C. (1999). Competitor-focused accounting: an exploratory note. Accounting, Organizations and Society, 24, 583-595.

Guilding, C., Cravens, K. S., \& Tayles, M. (2000). An international comparison of strategic management accounting practices. Management Accounting Research, 11, 113135.

Guilding, C., \& McManus, L. (2002). The incidence, perceived merit and antecedents of customer accounting: an exploratory note. Accounting, Organizations and Society, 27, 45-59.

Gul, F. A., \& Chia, Y. M. (1994). The effects of management accounting systems, perceived environmental uncertainty and decentralization on managerial performance: a test of three-way interaction. Accounting, Organizations and Society, 19, 413-426.

Gupta, A. K. (1987). SBU strategies, corporate-SBU relations, and SBU effectiveness in strategy implementation. Academy of Management Journal, 30, 477-500.

Hair, J. F., Anderson, R. E., Tatham, R. L., \& Black, W. C. (1998). Multivariate data analysis (5th ed.). Upper Saddle River: Prentice Hall. 
Haldma, T., \& Laats, K. (2002). Contingencies influencing the management accounting practices of Estonian manufacturing companies. Management Accounting Research, 13, 379-400.

Hambrick, D. D. (1980). Operationalizing the concept of business-level strategy in research. Academy of Management Review, 5, 567-575.

Hartmann, F. G. H., \& Moers, F. (1999). Testing contingency hypotheses in budgetary research: an evaluation of the use of moderated regression analysis. Accounting, Organizations and Society, 24, 291-315.

Hartmann, F. G. H., \& Moers, F. (2003). Testing contingency hypotheses in budgetary research using moderated regression analysis: a second look. Accounting, Organizations and Society, 28, 803-809.

Heagy, C. D. (1991). Determining optimal quality costs by considering cost of lost sales. Journal of Cost Management, 5, 64-72.

Hergert, M., \& Morris, D. (1989). Accounting data for value chain analysis. Strategic Management Journal, 10, 175-188.

Hoque, Z., \& James, W. (2000). Linking balanced scorecard measures to size and market factors: impact on organizational performance. Journal of Management Accounting Research, 12, 1-17.

Hoque, Z. (2001). Strategic Management Accounting. Oxford: Chandos Publishing.

Hunger, D. J., \& Wheelen, T. L. (1996). Strategic management (5th ed.). Reading: Addison-Wesley Publishing.

Ittner, C. D., \& Larcker, D. F. (1997). Quality strategy, strategic control systems, and organizational performance. Accounting, Organizations and Society, 22, 293-314.

Ittner, C. D., \& Larcker, D. F. (2001). Assessing empirical research in managerial accounting: a value-based management perspective. Journal of Accounting and Economics, 32, 349-410.

Ittner, C. D., Larcker, D. F., \& Randall, T. (2003). Performance implications of strategic performance measurement in financial services firms. Accounting, Organizations and Society, 28, 715-741.

Jacob, R. (1994). Why some customers are more equal than others. Fortune, 130, 215220.

Jaworski, B. J., \& Kohli, A. K. (1993). Market orientation: antecedents and consequences. Journal of Marketing, 57, 53-70. 
Johnson, T. H., \& Kaplan, R. S. (1987). Relevance Lost: The Rise and Fall of Management Accounting. Boston: Harvard Business School Press.

Jones, L. (1988). Competitor cost analysis at Caterpillar. Strategic Finance, 77, 32-38.

Joreskog, K. G., \& Sorbom, D. (1993). LISREL 8: Structural equation modelling with the SIMPLIS command language. Lincolnwood, IL: Scientific Software International.

Kaplan, R. S. (1984). The evolution of management accounting. The Accounting Review, 59, 390-418.

Kaplan, R. S., \& Atkinson, A. A. (1989). Advanced management accounting (2nd ed.). Upper Saddle River: Prentice Hall.

Kaplan, R. S., \& Norton, D. P. (1992). The balanced scorecard: measures that drive performance. Harvard Business Review, 70, 71-80.

Kaplan, R. S., \& Norton, D. P. (1996). The balanced scorecard: translating strategy into action. Boston: Harvard Business School Press.

Lance, C. E., \& Vandenberg, R. J. (2002). Confirmatory factor analysis. In F. Drasgow, \& N. Schmitt (Eds.), Measuring and analyzing behaviour in organizations: advances in measurement and data analysis. San Francisco: Jossey-Bass.

Langfield-Smith, K. (1997). Management control systems and strategy: a critical review. Accounting, Organizations and Society, 22, 207-232.

Lau, C. M., \& Lim, E. W. (2002). The intervening effects of participation on the relationship between procedural justice and managerial performance. The British Accounting Review, 34, 55-75.

Libby, T., \& Waterhouse, J. H. (1996). Predicting change in management accounting systems. Journal of Management Accounting Research, 8, 137-150.

Libby, T., Salterio, S. E., \& Webb, A. (2004). The balanced scorecard: the effects of assurance and process accountability on managerial judgement. The Accounting Review, 79, 1075-1094.

Lord, B. R. (1996). Strategic management accounting: the emperor's new clothes?. Management Accounting Research, 7, 347-367.

Mahama, H. (2006). Management control systems, cooperation and performance in strategic supply relationships: a survey in the mines. Management Accounting Research, 17, 315-339.

Merchant, K. A. (1981). The design of the corporate budgeting system: influences on managerial behaviour and performance. The Accounting Review, 56, 813-829. 
Mia, L. (1989). The impact of participation in budgeting and job difficulty on managerial performance and work motivation: a research note. Accounting, Organizations and Society, 14, 347-357.

Mia, L., \& Chenhall, R. H. (1994). The usefulness of management accounting systems, functional differentiation and managerial effectiveness. Accounting, Organizations and Society, 19, 1-13.

Mia, L., \& Clarke, B. (1999). Market competition, management accounting systems and business unit performance. Management Accounting Research, 10, 137-158.

Miles, R. E., \& Snow, C. C. (1978). Organizational strategy, structure and process. New York: McGraw-Hill.

Mintzberg, H. (1987a). The strategy concept I: five Ps for strategy. California Management Review, 30, 11-24.

Mintzberg, H. (1987b). Crafting strategy. Harvard Business Review, 65, 66-75.

Mintzberg, H., Quinn, J. B., \& Voyer, J. (1995). The strategy process. Englewood Cliffs, NJ: Prentice-Hall.

Monden, Y., \& Hamada, K. (1991). Target costing and kaizen costing in Japanese automobile companies. Journal of Management Accounting Research, 3, 16-34.

Moon, P., \& Bates, K. (1993). Core analysis in strategic performance appraisal. Management Accounting Research, 4, 139-152.

Moores, K., \& Chenhall, R. H. (1993). Strategic Management Accounting. Brisbane: John Wiley and sons.

Moores, K., \& Yuen, S. (2001). Management accounting systems and organizational configuration: a life-cycle perspective. Accounting, Organizations and Society, 26, 351389.

Naranjo-Gil, D., \& Hartmann, F. (2007). Management accounting systems, top management team heterogeneity and strategic change. Accounting, Organizations and Society, 32, 735-756.

Narver, J. C., \& Slater, S. F. (1990). The effect of market orientation on business profitability. Journal of Marketing, 54, 20-35.

Nouri, H., \& Parker, R. J. (1998). The relationship between budget participation and job performance: the roles of budget adequacy and organizational commitment. Accounting, Organizations and Society, 23, 467-483. 
Nyamori, R. O., Perera, M. H. B., \& Lawrence, S. R. (2001).The concept of strategic change and implications for management accounting research. Journal of Accounting Literature, 20, 62-83.

O’Connor, N. G., Chow, C. W., \& Wu, A. (2004). The adoption of "Western" management accounting/controls in China's state-owned enterprises during economic transition. Accounting, Organizations and Society, 29, 349-375.

O’Connor, N. G., Deng, J., \& Luo, Y. (2006). Political constrains, organization design and performance measurement in China's state-owned enterprises. Accounting, Organizations and Society, 31, 157-177.

Oliver, L. (1991). Accountants as business partners. Management Accounting, 72, 4042.

Otley, D. T. (1980). The contingency theory of management accounting: achievement and prognosis. Accounting, Organizations and Society, 4, 413-428.

Otley, D. (1999). Performance management: a framework for management control sysems research. Management Accounting Research, 10, 363-382.

Palmer, R. J. (1992). Strategic goals and objectives and the design of strategic management accounting systems. Advances in Management Accounting, 1, 179-204.

Porter, M. E. (1996). What is strategy?. Harvard Business Review, 74, 61-78.

Parker, R. J., \& Kyj, L. (2006). Vertical information sharing in the budgeting process. Accounting, Organizations and Society, 31, 27-45.

Perrera, S., Harrison, G., \& Poole, M. (1997). Customer-focused manufacturing strategy and the use of operations-based non-financial performance measures: a research note. Accounting, Organizations and Society, 22, 557-572.

Rangone, A. (1997). Linking organizational effectiveness, key success factors and performance measures: an analytical framework. Management Accounting Research, 8, 207-219.

Reardon, J., Miller, C., Vida, I., \& Kim, I. (2005). The effects of ethnocentrism and economic development on the formation of brand and ad attitudes in transitional economies. European Journal of Marketing, 39, 737-754.

Reid, G. C., \& Smith, J. A. (2000). The impact of contingencies on management accounting system development. Management Accounting Research, 11, 427-450.

Rickwood, C. P., Coates, J. B., \& Stacey, R. J. (1990). Stapylton: strategic management accounting to gain competitive advantage. Management Accounting Research, 1, 37-49. 
Roslender, R. (1995). Accounting for strategic positioning: responding to the crisis in management accounting. British Journal of Management, 6, 45-57.

Roslender, R., Hart, S., \& Ghosh, J. (1998). Strategic management accounting: refocusing the agenda. Management Accounting, 76, 44-46.

Roslender, R., \& Hart, S. (2003). In search of strategic management accounting: theoretical and field study perspectives. Management Accounting Research, 14, 255279.

Rowe, C., Birnberg, J. G., \& Shields, M. D. (in press). Effects of organizational process change on responsibility accounting and manager's revelations of private knowledge. Accounting, Organizations and Society.

Ryan, B. (1995). Strategic accounting for management. London: The Dryden Press.

Schumacker, R. E., \& Lomax, R. G. (1996). A beginner's guide to structural equation modeling. Mahwah, NJ: Lawrence Erlbaum Accociates.

Scott, T. W., \&. Tiessen, P. (1999). Performance measurement and managerial teams. Accounting, Organizations and Society, 24, 263-285.

Selto, F. H., Renner, C. J., \& Young, S. M. (1995). Assessing the organizational fit of a just-in-time manufacturing system: testing selection, interaction and systems models of contingency theory. Accounting, Organizations and Society, 20, 665-684.

Shank, J. K., \& Govindarajan, V. (1988). Making strategy explicit in cost analysis: a case study. Sloan Management Review, 29, 19-30.

Shank, J. K., \& Govindarajan, V. (1992). Strategic cost management: the value chain perspective. Journal of Management Accounting Research, 4, 179-197.

Shank, J. K., \& Govindarajan, V. (1993). Strategic cost management, New York: The Free Press.

Shank, J. K. (1996). Analysing technology investment - from NPV to strategic cost management (SCM). Management Accounting Research, 7, 185-197.

Sharma, D. S. (2002). The differential effect of environmental dimensionality, size and structure on budget system characteristics in hotels. Management Accounting Research, $13,101-130$.

Shields, M. D., \& Young, M. S. (1991). Managing product life cycle costs: an organizational model. Journal of Cost Management, 5, 39-52. 
Shields, M. D., \& Deng, J. F., \& Kato, Y. (2000). The design and effects of control systems: tests of direct and indirect-effects models. Accounting, Organizations and Society, 25, 185-202.

Shortell, S. M., \& Zajac, E. J. (1990). Perceptual and archival measures of Miles and Snow's strategic types: a comprehensive assessment of reliability and validity. Academy of Management Journal, 33, 817-832.

Simmonds, K. (1981). Strategic management accounting. Management Accounting, 59, 26-29.

Simmonds, K. (1982). Strategic management accounting for pricing: a case example. Accounting and Business Research, 47, 206-214.

Simmonds, K. (1986). The accounting assessment of competitive position. European Journal of Marketing, 20, 16-32.

Simons, R. (1987). Accounting control systems and business strategy: an empirical analysis. Accounting, Organizations and Society, 12, 357-374.

Slater, S. F., \& Narver, J. C. (1994). Market orientation, customer value, and superior performance. Business Horizons, 37, 22-28.

Smith, K. G., Guthrie, J. P., \& Chen, J. (1989). Strategy, size and performance. Organization Studies, 10, 63-81.

Smith, M. (1997). Strategic management accounting. Oxford: Butterworth-Heinemann.

Smith, D., \& Langfield-Smith, K. (2004). Structural equation modelling in management accounting research: critical analysis and opportunities. Journal of Accounting Literature, 23, 49-86.

Szendi, J. Z., \& Shum, C. (1999). Strategic management accounting practices in Latin America. Journal of Accounting and Finance Research, 1-13.

Tayles, M., Bramley, A., Adshead, N., \& Farr, J. (2002). Dealing with the management of intellectual capital: the potential role of strategic management accounting. Accounting, Auditing \& Accountability Journal, 15, 251-267.

Tomkins, C., \& Carr, C. (1996). Reflections on the papers in this issue and a commentary on the state of strategic management accounting. Management Accounting Research, 7, 271-280.

Vandenbosch, B. (1999). An empirical analysis of the association between the use of executive support systems and perceived organizational competitiveness. Accounting, Organizations and Society, 24, 77-92. 
Walker, O. C., Boyd, H. W., \& Larreche, J. (1998). Marketing strategy: planning and implementation (3rd ed.). Boston: IRWIN/McGraw-Hill.

Ward, K. (1992). Strategic Management Accounting. Oxford: Butterworth-Heineman.

Ward, K. (1993). Accounting for a "sustainable competitive advantage". Management Accounting, 71, 36-38.

Waterhouse, J., \& Tiessen, P. (1978). A contingency framework for management accounting systems research. Accounting, Organizations and Society, 3, 65-76.

Wilson, R. M. S. (1991). Strategic management accounting. In D. Ashton, T. Hopper, \& R. W. Scapens (Eds.), Issues in management accounting. New York: Prentice Hall.

Wooldridge, B., \& Floyd, S. W. (1990). The strategy process, middle management involvement and organizational performance. Strategic Management Journal, 11, 231241.

Zeithaml, V. A. (2000). Service quality, profitability, and the economic worth of customers: what we know and what we need to learn. Academy of Marketing Science Journal, 28, 67-85. 
Figure 1:

Contingency model of strategic management accounting (main effects model)

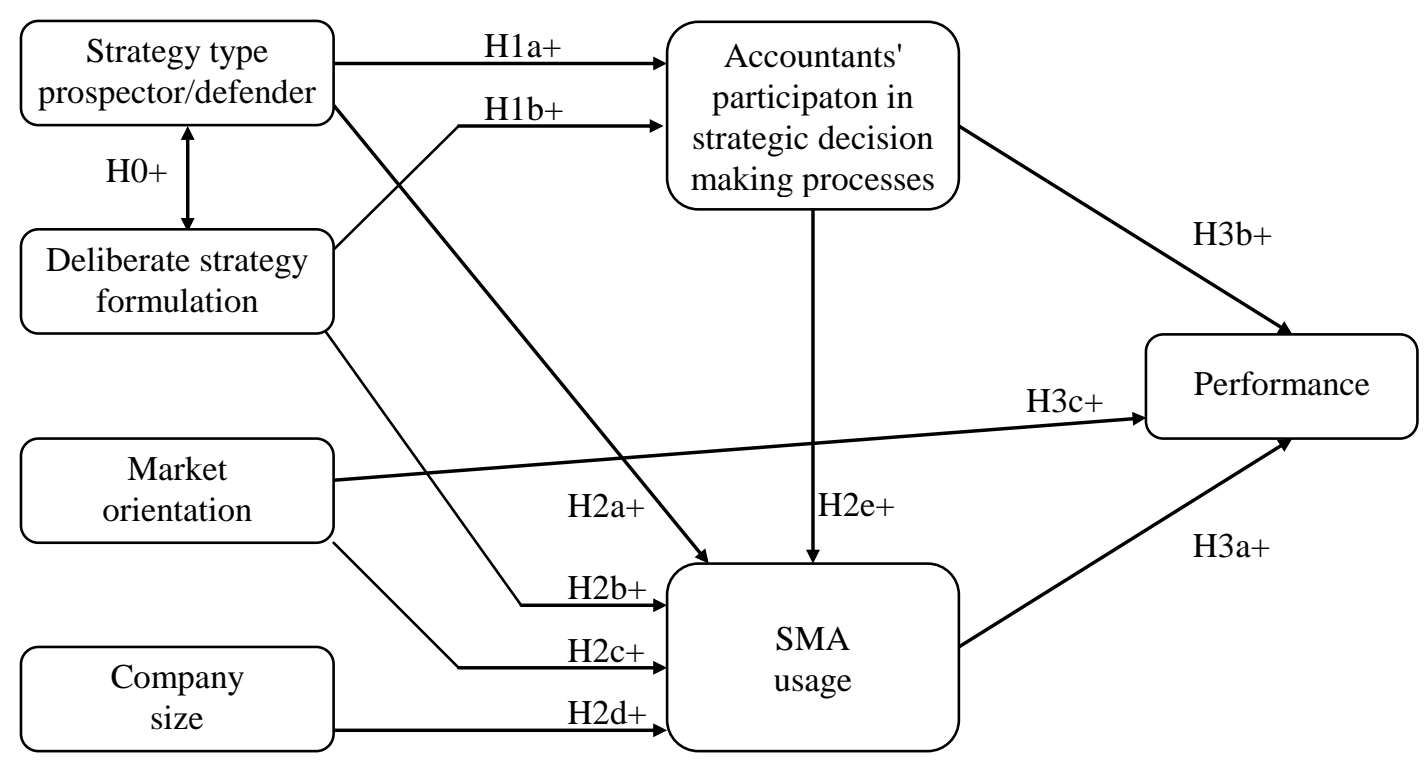


Figure 2: Structural model parameter estimates (standardized solution)

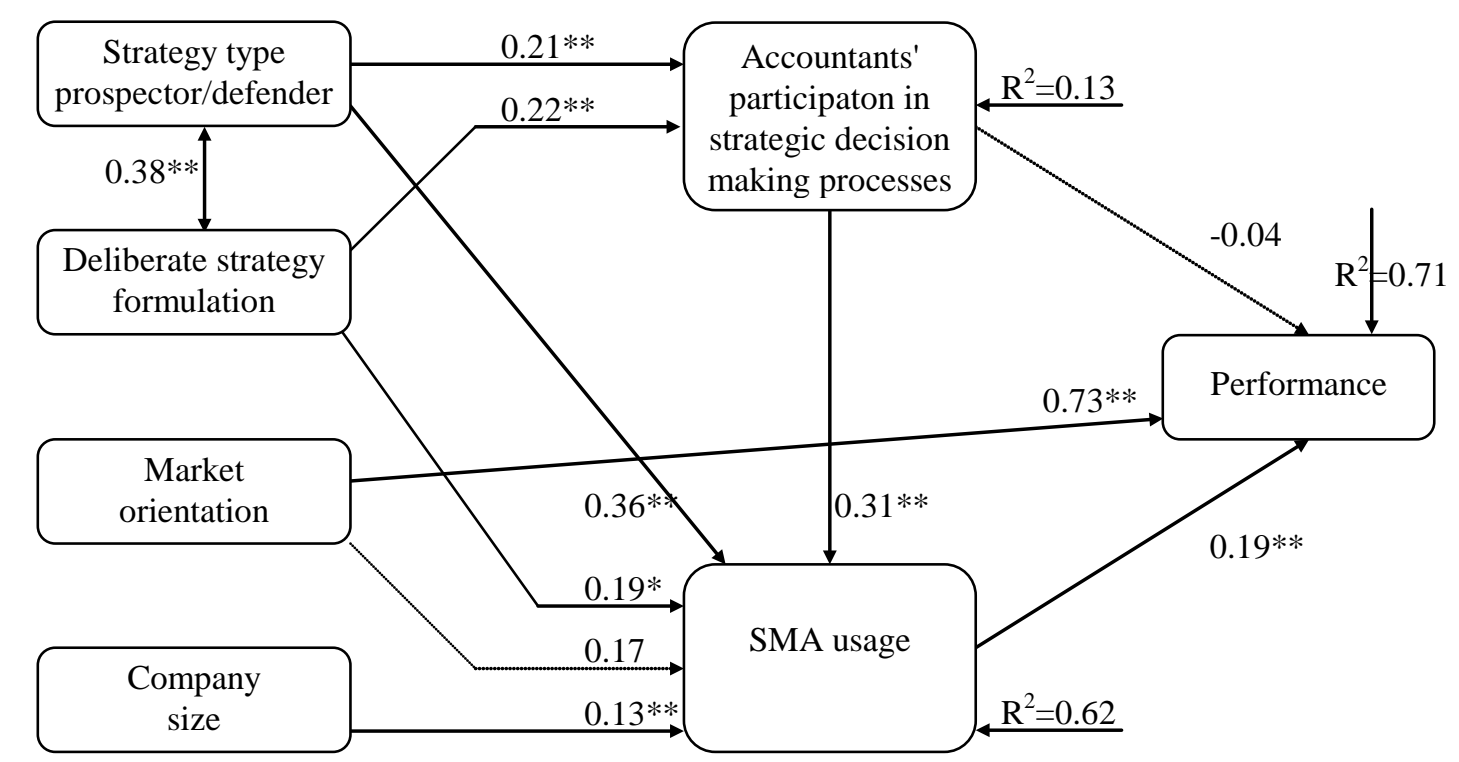

*: Coefficent is statistically significant at $p<0.05$ level (one-tail).

**: Coefficient is statistically significant at $p<0.05$ level (two-tail).

Goodness of fit criteria: $\chi^{2}=221,96$; d.f. $=156$; sig.level $=0.001$; NFI $=0.932$; NNFI $=$ 0.965; CFI $=0.971 ;$ SRMR $=0.060 ;$ RMSEA $=0.047 ;$ GFI $=0.885$. 
Table 1: Management accounting techniques exhibiting strategic orientation

\begin{tabular}{|c|c|}
\hline $\begin{array}{l}\text { SMA technique } \\
\text { categories }\end{array}$ & SMA techniques ${ }^{4}$ \\
\hline Costing & $\begin{array}{l}\text { 1. Attribute costing (Bromwich, 1990; Roslender and Hart, 2003) } \\
\text { 2. Life-cycle costing (Czyzewski and Hull, 1991; Shields and Young, 1991; Dunk, } \\
\text { 2004) } \\
\text { 3. Quality costing (Heagy, 1991; Belohlav, 1993) } \\
\text { 4. Target costing (Monden and Hamada, 1991; Cooper and Slagmulder, 1999) } \\
\text { 5. Value-chain costing (Hergert and Morris, 1989; Shank and Govindarajan, 1992; } \\
\text { Dekker, 2003) }\end{array}$ \\
\hline $\begin{array}{l}\text { Planning, } \\
\text { control and } \\
\text { performance } \\
\text { measurement }\end{array}$ & $\begin{array}{l}\text { 1. Benchmarking (Elnathan et al; 1996, Brownlie, 1999) } \\
\text { 2. Integrated performance measurement (Kaplan and Norton, 1992; 1996; Ittner et al, } \\
\text { 2003; Libby et al, 2004; Chenhall, 2005) }\end{array}$ \\
\hline $\begin{array}{l}\text { Strategic } \\
\text { decision-making }\end{array}$ & $\begin{array}{l}\text { 1. Strategic costing (strategic cost management) (Shank and Govindarajan, 1988; } \\
\text { 1993; Shank, 1996) } \\
\text { 2. Strategic pricing (Simmonds, 1982; Rickwood et al, 1990) } \\
\text { 3. Brand valuation (Guilding, 1992; Cravens and Guilding, 1999) }\end{array}$ \\
\hline $\begin{array}{l}\text { Competitor } \\
\text { accounting }\end{array}$ & $\begin{array}{l}\text { 1. Competitor cost assessment (Simmonds, 1981; Jones, 1988; Bromwich, 1990; } \\
\text { Ward, 1992) } \\
\text { 2. Competitive position monitoring (Simmonds, 1986; Rangone, 1997) } \\
\text { 3. Competitor performance appraisal (Moon and Bates, 1993) }\end{array}$ \\
\hline $\begin{array}{l}\text { Customer } \\
\text { accounting }\end{array}$ & $\begin{array}{l}\text { 1. Customer profitability analysis (Bellis-Jones, 1989; Ward, 1992; Zeithaml, 2000) } \\
\text { 2. Lifetime customer profitability analysis (Foster and Gupta, 1994; Jacob, 1994) } \\
\text { 3. Valuation of customers as assets (Slater and Narver, 1994; Foster and Gupta, 1996; } \\
\text { Zeithaml, 2000) }\end{array}$ \\
\hline
\end{tabular}

\footnotetext{
${ }^{4}$ Brief descriptions of these techniques are provided in the appendix, while more extensive descriptions of most of these techniques are provided in Guilding et al (2000) and Guilding and McManus (2002).
} 
Table 2: Industry classification of the sampled companies

\begin{tabular}{|l|r|c|}
\hline \multicolumn{1}{|c|}{ Industry } & $\begin{array}{c}\text { Number of } \\
\text { firms }\end{array}$ & $\begin{array}{c}\text { Percentage } \\
\text { of sample }\end{array}$ \\
\hline Agriculture & 1 & 0.5 \\
\hline Mining & 2 & 1.0 \\
\hline Manufacturing & 108 & 56.0 \\
\hline Public services and utilities & 10 & 5.2 \\
\hline Construction & 9 & 4.7 \\
\hline Wholesale and retail & 30 & 15.5 \\
\hline Accommodation and food services & 6 & 3.1 \\
\hline Transportation and logistics services & 13 & 6.7 \\
\hline Financial intermediation services & 8 & 4.1 \\
\hline Real estate and other commercial services & 6 & 3.1 \\
\hline Total & 193 & 100.0 \\
\hline
\end{tabular}

Table 3: Schedule of companies represented in interviews

\begin{tabular}{|c|l|}
\hline Interviewee & \multicolumn{1}{c|}{ Nature of Company } \\
\hline A & $\begin{array}{l}\text { A government owned railway operator that has been accumulating losses for } \\
\text { many years. The company is subject to powerful trade union influence. }\end{array}$ \\
\hline B & $\begin{array}{l}\text { A telecommunications company that is owned by an Austrian based } \\
\text { multinational. }\end{array}$ \\
\hline C & A hotel operator that leases about 2\% of the Slovenian coastline. \\
\hline D & A regional freight delivery company. \\
\hline E & $\begin{array}{l}\text { An electrical equipment manufacturer with manufacturing facilities on all } \\
\text { contintents. }\end{array}$ \\
\hline F & $\begin{array}{l}\text { A manufacturer of electrical home appliances with international brand } \\
\text { recognition. }\end{array}$ \\
\hline G & A manufacturer of basic construction materials with a large mining operation. \\
\hline H & A large mutual insurance company. \\
\hline I & $\begin{array}{l}\text { Manufacturer of sports equipment with an internationally recognisable brand } \\
\text { name. }\end{array}$ \\
\hline J & Employee owned furniture manufacturer. \\
\hline
\end{tabular}


Table 4: Correlation coefficents among constructs in the measurement model

\begin{tabular}{|c|c|c|c|c|c|c|c|}
\hline & Str-PD & Str-DE & Mo & Size & Part & SMAu & Perf \\
\hline Business strategy (Str-PD) & 1 & & & & & & \\
\hline Strategy deliberation (Str-DE) & $* * 0,39$ & 1 & & & & & \\
\hline Market orientation (Mo) & $* * 0,58$ & $* * 0,61$ & 1 & & & & \\
\hline Company size (Size) & $* 0,17$ & 0,05 & 0,12 & 1 & & & \\
\hline Participation (Part) & $* * 0,29$ & $* * 0,28$ & $* * 0,33$ & $-0,07$ & 1 & & \\
\hline SMA usage(SMAu) & $* * 0,63$ & $* * 0,53$ & $* * 0,62$ & $* 0,20$ & $* * 0,51$ & 1 & \\
\hline Performance (Perf) & $* * 0,72$ & $* * 0,41$ & $* * 0,83$ & $* 0,17$ & $* * 0,29$ & $* * 0,59$ & 1 \\
\hline
\end{tabular}

*Coefficent is statistically significant at $p<0.05$ level (two-tail),

$* *$ Coefficient is statistically significant at $p<0.01$ level (two-tail). 